\title{
A DEVELOPMENT FRAMEWORK FOR PERFORMANCE-BASED OUTPUT SPECIFICATIONS TO ENCOURAGE INNOVATION IN PUBLIC-PRIVATE PARTNERSHIPS
}

\author{
By \\ Demokrat Qordja \\ BEng. Epoka University, Albania, 2013
}

\author{
A Research Project \\ presented to Ryerson University \\ in partial fulfillment of the \\ requirements for the degree of \\ Master of Engineering \\ in the Program of \\ Civil Engineering \\ Toronto, Ontario, Canada, 2016 \\ (C) Demokrat Qordja 2016
}




\title{
A DEVELOPMENT FRAMEWORK FOR PERFORMANCE-BASED OUTPUT SPECIFICATIONS TO ENCOURAGE INNOVATION IN PUBLIC-PRIVATE PARTNERSHIPS
}

\begin{abstract}
Author`s Declaration
I hereby declare that I am the sole author of this research project. This is a true copy of the research project, including any required final revisions.

I authorize Ryerson University to lend this document to other institutions or individuals for the purpose of scholarly research.

I further authorize Ryerson University to reproduce this research project by photocopying or by other means, in total or in part, at the request of other institutions or individuals for the purpose of scholarly research.
\end{abstract}

I understand that my research project may be made electronically available to the public. 


\title{
A DEVELOPMENT FRAMEWORK FOR PERFORMANCE-BASED OUTPUT SPECIFICATIONS TO ENCOURAGE INNOVATION IN PUBLIC-PRIVATE PARTNERSHIPS
}

\author{
By Demokrat Qordja. \\ Ryerson University - Civil Engineering \\ Toronto, Ontario, Canada, 2016
}

\begin{abstract}
Public-Private Partnerships (PPPs) have been emerged as a successful delivery approach for driving largescale infrastructure projects to provide affordable services and to meet the public requirements. The successful development of performance-based output specifications (PSOS) for PPP infrastructure projects have been under the attention of many procurement agencies and public authorities. Many diverse groups from both public and private sector believe that the current practice of PSOS needs to be enhanced. The lack of guidance to ensure that the performance is properly linked with the designed end product is identified as the major challenge to develop a high quality PSOS. In this study, a set of performance criteria and a generic framework for developing high quality PSOS based on the hierarchy of system engineering approach is proposed. Moreover, two infrastructure projects were considered as case studies to evaluate the PSOS implemented and to compare the results obtained, with the proposed framework.
\end{abstract}




\section{Acknowledgements}

The author would like to thank and to express his deep appreciation to his advisor Dr. Arnold Yuan, for his help, patience and continuous support shown along the development of this research project. Dr. Yuan devoted his time and efforts to complete this research project successfully. His guidance and methodology used to perform this research project is greatly appreciated.

The author is very grateful to his family, friends and colleagues for their great support and encouragement provided, to successfully complete this study. 


\section{Table of Contents}

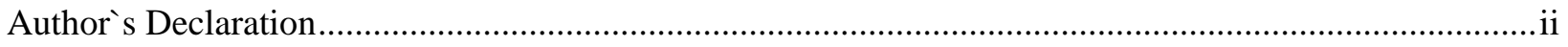

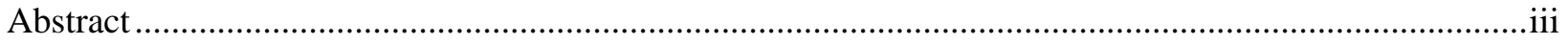

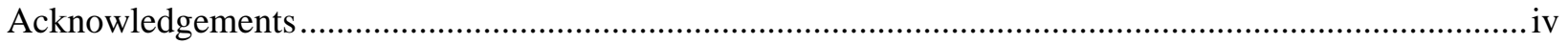

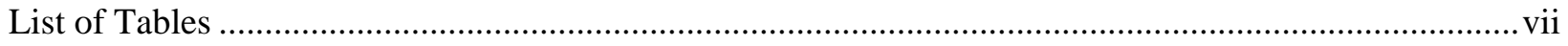

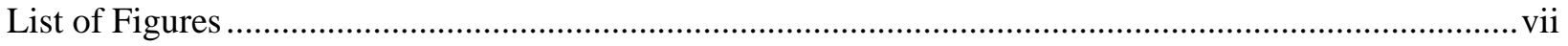

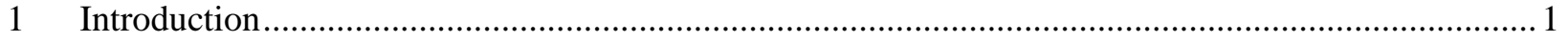

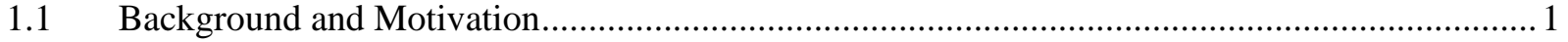

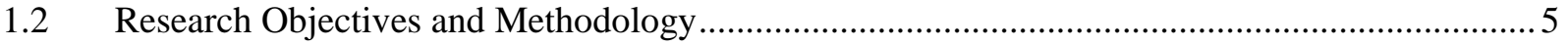

2 Procurement Process in PPP Infrastructure Projects....................................................................... 6

2.1 Procurement Methods and Established Criteria for Delivering PPP Infrastructure Projects ........ 6

$2.2 \quad$ Procurement Stages for PPP Infrastructure Projects ................................................................ 9

2.2.1 Request for Expressions of Interest (RFEI) ….........................................................

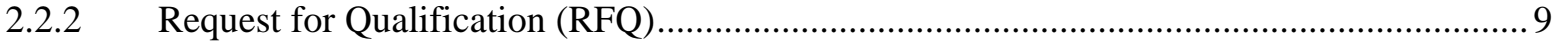

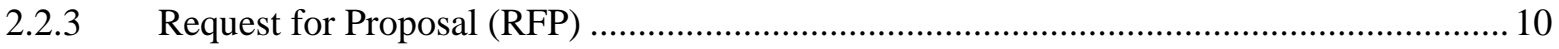

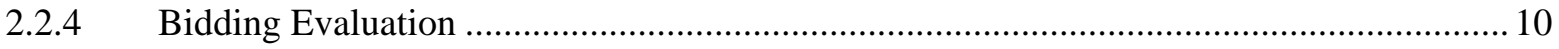

2.2.5 Detailed Negotiation with Preferred Bidders ................................................................. 11

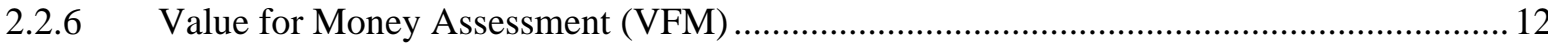

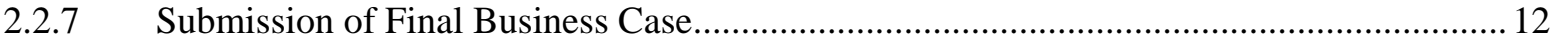

2.2.8 Commercial Closing and Financial Closing ….............................................................. 12

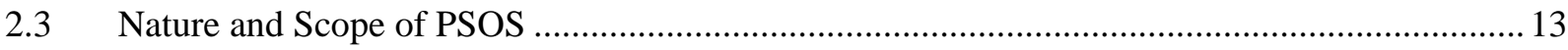

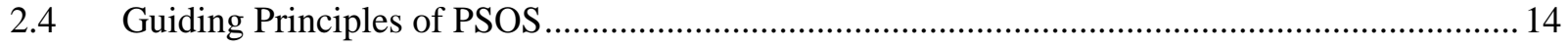

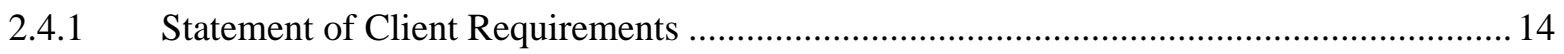

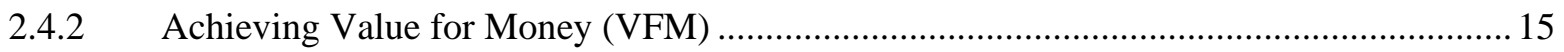

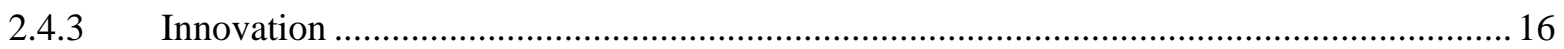

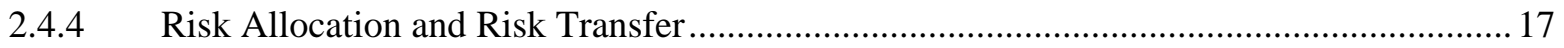

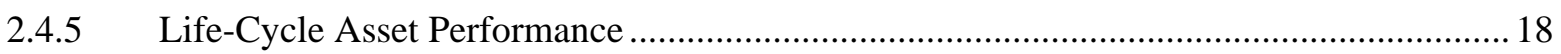

2.4.6 Performance Monitoring and Payment Mechanism............................................................ 19

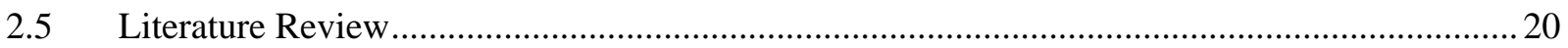

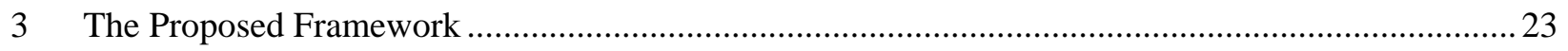

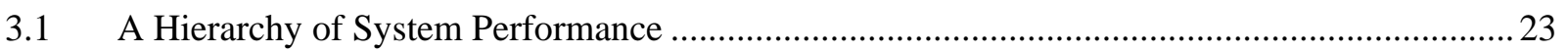

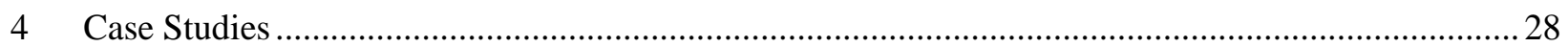

4.1 The Sea-to-Sky Highway Improvement Project ................................................................. 29

4.2 Performance-Based PSOS of Sea-to-Sky Improvement Project.............................................. 30 
4.3 Anthony Henday Drive Southeast Leg Ring Road ............................................................ 34

4.4 Performance-Based PSOS of Southeast Leg Ring Road ................................................... 36

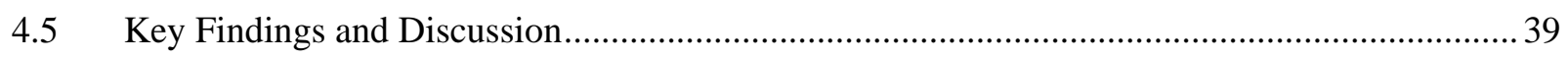

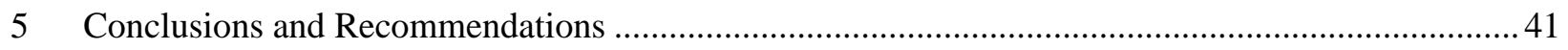

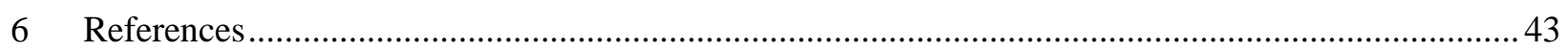




\section{List of Tables}

Table 1. The respective attributes for each infrastructure project. .....................................................28

Table 2. Baseline improvements and expected value for each section of the infrastructure project.......... 30

Table 3. A conceptual framework of performance-based PSOS for the Sea-to-Sky highway improvement

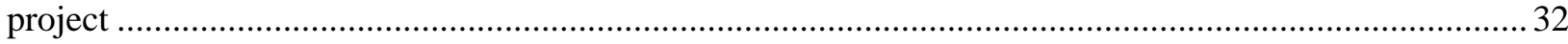

Table 4. General overview of the project scope and the associated benefits of DBFO model. ................ 35

Table 5. A conceptual framework of performance-based PSOS for the Southeast Ring Road.................. 37

\section{List of Figures}

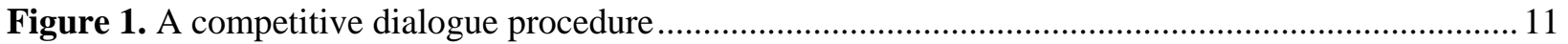

Figure 2. A simplified conceptual framework of a transportation engineering system ...........................24

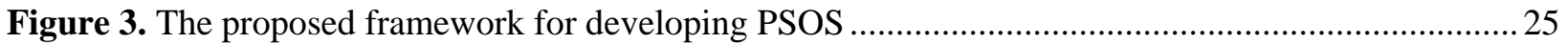

Figure 4. The top-down approach for the development of performance-based PSOS in PPP projects ..... 27 


\section{Introduction}

This section provides a background, indicating the influence of PPP approach in the Canadian market for delivering large-scale infrastructure projects. Among this section the significance of the PPP model for delivering high quality service, increasing public benefits and reducing the life-cycle cost is emphasized. The main characteristics and the fundamental components of the PPP approach are pointed out. Moreover, the different roles and responsibilities that the public and private sector play in the PPP are accentuated.

\subsection{Background and Motivation}

Public Private Partnerships (PPPs) have emerged as an important project delivery approach that has successfully delivered public infrastructure facilities all around the world. In Canada, PPPs are found to be very successful and are used as a key strategy for driving large-scale infrastructure projects to provide affordable service that meets the public requirements. PPP arrangements have a shown significant impact in the Canadian market by providing quality service, increasing the public benefits and reducing the lifecycle cost. PPPs represent an innovation in public procurement, whereby on one side the public sector wants to deliver the services with a high quality standard and on the other side the private sector wants to increase its ability to perform and invest public services in an efficient, effective and innovative manner.

As part of infrastructure development the PPP concept in the United Kingdom (UK), so called PFI, was initially lunched in 1992 as a legal framework for concessions in the UK to engage private capital investment to implement design and build infrastructure projects in the construction industry. Within the PFI framework the public authority determines the output specification of the services which needs to be performed by the private authority considering a predefined payment mechanism.

In 2011, the federal government of Canada suggested that the opportunity and benefits of using PPP in large-scale federal capital projects are required to be discovered and materialized. It was emphasized that all infrastructure projects with a lifespan more than 20 years and having a capital cost more than $\$ 100$ million should be evaluated for possible use of the PPP approach (Infrastructure Ontario, 2013). According to Infrastructure Ontario (IO) the alternative financing and procurement (AFP) is defined as a long term performance based approach to procuring public infrastructure projects, enhancing government ability to hold the private sector responsible for delivering public assets over their expected life spans. Under the PPP approach a major share of risk associated with infrastructure development is transferred to the private sector involving costs associated with overruns, schedule delays, unexpected maintenance and ongoing defects in the performed assets. 
Partnerships BC stated that public-private partnerships are better alternatives which must be used to provide affordable infrastructure that meet public needs. They defined the PPP approach as a legally binding contract between the government and private authority to develop public assets and deliver public services that allocates responsibilities and business risks among several proponents (Partnerships BC, 2003). One of the critical components of PPPs is the risk transfer from the public sector to the private sector. For instance, during the construction of large transportation infrastructure such as highways, railways, and transit systems, in addition to financing and building the infrastructure, the private company also assumes the responsibility for the risks related to the project. However, the common initiative is to combine the public and private sector capabilities for bringing benefits to both sectors.

Public-private partnerships across Canada and all around the world have shown their capability to best manage the social and economic infrastructure projects by producing value for taxpayers and engaging the private sector to perform and deliver the public services. The main characteristics of public-private partnerships are listed below (Akintoye \& Beck, 2009):

- PPP procurement approach provides an effective way of delivering Value for Money (VFM) in public infrastructure projects.

- PPPs provide an appropriate opportunity to improve cost effectiveness and to transfer the risk from the public to the private sector.

- PPPs encourage the private sector to deliver the asset in a cost-effective and efficient manner through the implementation of innovative measures and execution of PSOS.

- PPP undertakes a fair, transparent and competitive procurement process.

- PPPs provide a comprehensive opportunity for the private sector to secure long term investment in capital projects.

- Both public and private sectors provide their best capability to perform the project with different levels of involvement and responsibility.

In a typical PPP infrastructure project, both the public and the private sector have its own roles and responsibilities. The public sector determines the required service and leaves as much space as possible for the private sector to design, finance, construct, operate and maintain the asset over its life-cycle, typically of 30 years. The private sector assumes the responsibility of developing cost-effective solutions to manage all risks allocated to the project company in order to ensure that a positive value for money is achieved and the public interest is satisfied. Following criteria established by PPP agencies, the procurement undergoes through a fair, transparent and a competitive bidding process. After the facility is built, the public sector is still actively involved throughout the life-cycle of the project by monitoring the project performance to 
ensure that the facility meets the handback conditions (specified in the project agreement) at the end of the contract term.

The province of Ontario and many other provinces in Canada continue to embrace the PPP model for delivering public infrastructure. Indeed, each provincial and federal government have established their own agencies and departments committed to funding and promoting PPPs. Many procurement agencies maintain that PPP is the best model to deliver public infrastructure when the benefits exceed the cost. The federal government persist that they are leveraging greater values and generating efficiencies by inviting the private sector to deliver the public infrastructure (Infrastructure Ontario, 2015). A research study conducted at the University of Toronto (Siemiatycki \& Farooqi, 2012), found that PPPs cost 16\% more than traditional delivery methods. This occurs because the private sector pays higher interest rate than public sector. However, the public procurement agencies believe that without putting a fair price on the risks that affect projects, the taxpayers would never know whether PPPs are the best approach among various delivery models including the traditional design-bid-build method.

One of the key features of the PPP model is the flexibility of the private sector to deliver the required service. In other words, bundling together the design, construction, operation and maintenance of the asset allow the private sector to apply its technical expertise and develop innovative ways to deliver a high quality end product. In order to achieve a good quality end product, it is important to develop a good set of PSOS at the earlier procurement stage ensuring that value for money, innovation, risk allocation and risk transfer, and the overall life-cycle project performance is attained. Unlike the conventional methods which use the detailed prescriptive specifications to deliver the infrastructure, the PPP method relies on performancebased output specifications. Therefore, drafting a clear and effective PSOS by the public sector and ensuring that the private sector has a good understanding on those specifications is extremely important to meet the required outcomes. In order to have a better understanding of PSOS and its impact in PPP infrastructure projects, the following questions are addressed:

\section{1) What is PSOS?}

PSOS is a central part of the Request for Proposal (RFP) document that describes the client needs, functionality program and performance expectations. Being an important part of RFP document, it differs from the technical specifications in the traditional model in which the former is output oriented and the latter is more input focused.

\section{2) What is the current practice of PSOS and what does the public and private sector think of it?}


The current practice of PSOS relies on a polarization oriented spectrum. This means that the current PSOS is either too prescriptive or too vague that involve difficulties for the private sector to understand what the public sector exactly need. As a result the private sector complain that there is no room for innovation.

\section{3) What are the major challenges in developing a high quality PSOS?}

The major challenge to develop a high quality PSOS is the lack of guidance of how to link the performance with the designed end product. As a result this major challenge is influenced further by the lack of performance criteria and the lack of experience on how to breakdown the performance.

PPP agencies and relevant governmental departments have shown inadequate experience in producing comprehensive PSOS to deliver PPP infrastructure projects (Foster, 2012). It is highly recommended by PSOS writers that current experience, for developing high quality PSOS, should be enhanced (Regan, James Smith, \& P. E. D, 2015). The enhancement process is a challenging task which requires great efforts and technical expertise by both public and private sectors. The incentives embedded in the PPP model encourage innovation in the delivery of public assets. Therefore, innovation has been thought of as a major selling point in addition to risk allocation. Because the innovations contain risk, they are not always desirable. The primary determinant of innovation is the performance-based output specifications (PSOS). Through the development of PSOS, the public sector has more opportunity to manage and control the innovations provided by the private sector. However, some individuals, either from public or private sectors, thought that innovations were impaired by prescriptive PSOS. Hence, the PSOS must be developed in such a way to encourage innovations and should be aligned with the type of PPP project to ensure that the life-cycle objectives are realized in an efficient and cost-effective manner. To avoid these deficiencies, the current practice of the PPP approach can be enhanced by developing better PSOS which will encourage the innovative solutions and provide better value for taxpayers. In many procurement documents it is typically noted that performance-based output specifications do not meet required levels of performance and sometimes are developed as a combination with the prescriptive specifications. Whether the traditional model or the PPP model is used to deliver the required product, this methodology is essentially acceptable. When the design-build-finance-operate and maintain (DBFOM) procurement model is selected for performing the infrastructure project the PSOS are developed instead of prescriptive (input) specifications. In conjunction with the DBFOM procurement model, PSOS must be prepared in such a way not just to include the physical state of the build facility but also to facilitate the operation, maintenance, rehabilitation and even the handback requirements.

For PPP infrastructure projects three fundamental components are considered of great importance. First is the evaluation of a systematic procurement model necessary to promote the mutual benefits for both public 
and private sectors. Second is the establishment of a fair and competitive bidding process in order to provide sufficient awareness for the private sector and to select the successful proponent which has the best capabilities to deliver the project and meet client requirements. Third is the development and implementation of a good set of PSOS to encourage the private sector design, construction and operational innovation, risk transfer, optimizing value for money benefits and minimizing the life-cycle cost. Development of PSOS requires time and efforts of all participating stakeholders including public authorities, governmental agencies, project companies, and a dedicated performance monitoring team. The performance of the assets and integrated services can only be achieved by placing PSOS within a framework of life-cycle infrastructure management throughout the development, implementation, and operation phases of a PPP project.

\subsection{Research Objectives and Methodology}

This study aims to propose a framework for developing performance-based output specifications (PSOS) and to discuss the potential performance measures to improve the PSOS for PPP infrastructure projects. An in-depth research methodology including literature review, industry reports, procurement documents, research papers, academic articles and other available resources is conducted. A set of criteria to decompose and incorporate the performance measures among the life-cycle of PPP infrastructure projects are emphasized. The criteria identified are used in conjunction with the principles of system engineering approach and performance hierarchy, to propose a generic framework of developing PSOS for PPP infrastructure projects. In addition, two case studies have been analyzed and evaluated to support the research methodology. The case study results are qualitatively and quantitatively summarized. In both case studies, the results obtained are compared between each other and with the proposed framework. 


\section{Procurement Process in PPP Infrastructure Projects}

This section provides a general overview of the procurement process for delivering PPP infrastructure projects. The major procurement models to perform and deliver infrastructure projects are briefly described and ranked from the lowest level to the highest level of the private sector involvement. Also the five

important criteria established by the government of Ontario to help the procurement agencies in assessing and evaluating infrastructure projects are emphasized. Moreover, the stages for evaluating procurement documents and selecting the appropriate proponent to deliver the service are reviewed and summarized. Although this section may appear to be elementary for professionals involved in PPPs, it is a helpful introduction for beginners to better understand the procurement process and differences between traditional and PPP models. Also, differentiating the key elements of these procurement models is aimed at helping the reader in developing a clear understanding of why the PPP procurement method is selected as the best strategy to deliver the infrastructure projects and how the PSOS are considered an essential part of procurement documents.

\subsection{Procurement Methods and Established Criteria for Delivering PPP Infrastructure Projects}

Overall this subsection discusses the procurement methods and the criteria used by Infrastructure Ontario to evaluate and select an AFP model. The province of Ontario has established a comprehensive guidance to help local government in the context of financing and procuring public goods and services. The guiding principles are presented as follows (Ministry of Infrastructure Renewal, 2004):

a) The public interest is paramount.

b) Value for Money (VFM) must be demonstrable.

c) Appropriate public control must be preserved.

d) Accountability between stakeholders must be maintained.

e) All procurement process must be transparent, fair and efficient to ensure the integrity of the whole process.

In general, PPP projects extend their work on the services outcomes, risk transfer and risk allocation as well as integrating the main components of design, build, service delivery and long-term operation and maintenance. Whether or not the project is going to be delivered as a PPP model, the involvement of the private sector in public infrastructure projects is inevitable. Also, the participation of the public sector in delivering public infrastructure is necessary in terms of providing benefits and value for taxpayers. Regardless the size and complexity of the project, the procurement models used to perform and deliver the 
infrastructure projects are presented and briefly discussed below. All models are structured and ranked from the lowest level to the highest level of the private sector involvement.

\section{Design-Bid-Build (DBB):}

In this most common traditional method the project owner undertakes a separate contract with the designer and the contactor. In general, the owner selects a design company to prepare and provide all the necessary design documents and a contactor to perform the construction work. Usually the owner prefers to use a fixed price or unit price for the construction contract. Once the contractor is selected, he/she enters into an agreement with the owner to construct the facility in accordance with the project plans and construction specifications.

\section{Design-Build (DB):}

It is also a traditional project delivery approach where the owner proposes a single contract and selects a single entity, known as a design-builder, to complete both the design and construction stages of the project. In contrast with the DBB model, this model is based on a single point of responsibility contract where the design build contractor is responsible to perform the project. This traditional procurement model is used to minimize the risks for the owner and reduce the project schedule delays.

\section{Design-Build-Finance (DBF):}

Under this approach, the private sector has full responsibility to design and construct the facility based on the specifications provided by the public sector. To perform the project, the private sector is assumed to generate its own financing since there is no payment provided by the public sector until the project is complete and is ready to operate. The main advantages for the public sector using this model are the cost and time benefits as well as the risk allocation and risk transfer to the private sector. Because the private sector will be responsible for the facility over the life-cycle, the cost limitation and the lack of innovation offered by the private sector are considered the main disadvantages of using this approach.

\section{Design-Build-Finance-Operate and Maintain (DBFOM):}

This is also referred as a Public-Private Partnership (PPP) procurement model. Under this procurement model, the private sector has its own responsibility to design, construct, finance, maintain and operate the facility. According to this delivery approach, the public sector does not own the proposed facility but pays the responsible contractor to design, construct, operate and maintain the facility over the contract period. Once the contract has expired the owner of the facility either remains as the private sector or the facility is returned to the public sector, depending on the contract terms and the conditions setting out. Based on the 
project agreement, the performance-based payments and a single contract are used to deliver the integrated management services for the proposed facility.

In order to implement the procurement methods mentioned above, the government of Ontario has proposed and assessed the 5 principal criteria to examine the financial and procurement methods available to deliver infrastructure projects. The proposed criteria are described briefly as follows:

\section{The Financial Criterion:}

This criterion is used to evaluate which procurement method provides a better value for taxpayers referring to a specific project using the cost-effective financial terms. The key issue here is to point out what are the current available financing tools to deliver the project. The involvement of public sector would incorporate sufficient incentives to support the risk transfer and an effective payment mechanism associated with the service outcomes.

\section{The Technical Criterion:}

Under this criterion, the technical issues that would have a significant impact on the procurement method are emphasized. Moreover, clear and adequate technical specifications need to be appropriately addressed to satisfy the technical requirements of the infrastructure project.

\section{The Operational Criterion:}

This criterion relies on what would be the operational issues that will affect the performance of the project. The performance standards must be determined and accumulated to specify the public and private sector objectives and to identify the best parties to manage and perform those standards.

\section{The Public Policy:}

The aim of this criterion is to clearly understand the public policy and the regulatory constraints in terms of how they may impact the choice of the procurement model. Also, another goal of the criterion is to emphasize the effects of public policy framework on public infrastructure and what is the involvement of the public sector under this governance.

\section{Implementation:}

Public infrastructure projects should be executed in accordance with the proposed criteria by selecting the most comprehensive procurement model which will bring value and fulfil the required standards. The purpose of implementing the proposed criteria in evaluating procurement delivery models is to bring the government, municipalities, and public-private sectors together in order to achieve financial resources to 
support infrastructure investment, innovative opportunities for the public sector, and best procurement and management practices to ensure value for money.

\subsection{Procurement Stages for PPP Infrastructure Projects}

This subsection discusses the main stages of the procurement process used by procurement agencies to evaluate the proposed bidding documents and to select the preferred proponent for delivering PPP infrastructure projects.

\subsubsection{Request for Expressions of Interest (RFEI)}

Depending on the type and complexity of the infrastructure project the proponent may decide to measure the quality of bids (Ministry of Infrastructure Renewal, 2004). Regardless the method used to measure the public interest, the process must be fair and transparent. The purpose of RFEI is to inform the bidding proponents about the project requirements that the public sector needs to be delivered. It also serves as a communication tool between the public sector and the bidding proponents to ensure that the proposed structure of the project meets the market condition. Usually the RFEI is used to provide the public sector a better view of the proponents that offer the best capabilities to move forward in terms of managing the project activities among the lifetime frame of the contract.

The information provided in the RFEI should be sufficient and meaningful to permit the potential bidders to determine whether they have the experience and the technical capabilities to develop a suitable bid. The RFEI document may contain a brief description of the public sector background and a brief overview of the proposed project, objectives and if they fit into the framework of public sector requirements. Furthermore, the duration of the contract, the identification of the associated risks, the specific constraints such as financial resources, payment mechanism, and project details are other important components that must be involved in the RFEI. Apart from the information demonstrated in the RFEI, the bidding proponents have to prepare their response in accordance with RFEI conditions. Their response must include specific information regarding the details of the proposed bid, responsibilities and area of expertise, resource funding, conflict of interest etc. The RFEI should reflect on the objectives of the proponents and must be reviewed carefully in order to select a shortlist whom will later be invited to submit their final bids for the project.

\subsubsection{Request for Qualification (RFQ)}

The request for qualification is released after the RFEI is issued. This approach is important to pre-qualify the shortlist bidders ensuring that they provide all the necessary technical and financial capabilities to perform the service. The bidders must be qualified based on the criteria set out in the RFEI proposal. 
Additionally, the preferred bidders can be assessed on their ability to work consistently with the public sector in a long-term relationship for delivering the infrastructure service. Only the bidders that will satisfy the evaluation criteria of the RFEI will be qualified. The rest will be automatically removed from the prequalification process.

During the evaluation process the legal entities, responsible for qualification of the bidders, have to consider the bidder experience and track record in delivering similar infrastructure projects under a long-term contractual relationship. Funding resources and the opportunity for innovation of the public sector are additional criteria which have to be considered. The bidding proponents are encouraged to collaborate between each other and to clearly define the role of each member to successfully deliver the project scope. The number of pre-qualified bidders varies from one project to another, but a list of 3-4 bidders will suffice. The shortlist bidders should submit their final bids prior to the next stage of the procurement process.

\subsubsection{Request for Proposal (RFP)}

After evaluating the request for qualification the final process of the competitive bidder is to provide the Request for Proposal (RFP). The RFP should clearly describe the procurement process and provide sufficient information for the selected bidder to make a decision for the proposed project. It has to be assessed and prepared under the legal entities to avoid conflicts and ensure an efficient bidding process. Selection of successful bidders is based on the criteria set out in the RFP.

The RFP should contain detailed information regarding the bidder capability, relevant experience, financial efforts, project purpose and objectives, output-specifications to be performed, key performance indicators, risk allocation and payment mechanism, public sector function etc. Among this phase the shortlist bidders are encouraged to prepare a Value for Money (VFM) analysis to clarify the public sector expectations. The final objective is to achieve a final VFM assessment and to select the preferred bidder which provides the best overall VFM benefits.

\subsubsection{Bidding Evaluation}

The policy and standard framework states that during the bidding process the contracting authorities should indicate and implement the legal obligations and the procurement rules such as equal treatment, nondiscrimination, and transparency. In order to assess the proposed bids a legal entity should be set up. The role of the legal entity is to evaluate bids and identify the potential bidders who have satisfied the requirements for delivering the service (HKIS, 2009). The assessment will be conducted in conformity with the legislation and regulatory policy set out in the bidding documents. A preliminary assessment of the project scope should be undertaken to highlight the service delivery outcomes. 
The selected bidders are invited to prepare and present a presentation to identify their objectives and highlight the key features necessary to perform the service. The evaluation team must fairly evaluate the presentations and provide equal opportunity to each bidder. The presentation is held after the written proposals are submitted. This process is important for the evaluation team to review and identify issues that each bidder must clarify and re-formulate. The financial criteria is another important component to be considered during the evaluation process. This criteria provides additional opportunities for the private sector to generate innovative solutions. It also helps the public sector to understand the objectives of the private sector and to ensure that these objectives meet the public sector expectations.

\subsubsection{Detailed Negotiation with Preferred Bidders}

After the bidding evaluation process is completed the negotiation with the preferred bidder will take place to ensure that the public sector will obtain the service outcomes through the best contracting models. A full negotiation process with the preferred bidder is conducted. This stage of the procurement process is helpful for the public sector to undertake a comparison of the selected bidder and to finalize the selection process based on the criteria of which the bidder provides their potential abilities to satisfy and fulfil the public sector objectives. A negotiation team should be established to assess the negotiation process based on the predefined negotiation strategy. A competitive dialogue procedure must be addressed to accumulate more space for the key project proponents to discuss the needs and the objectives of the proposed contract (OCG, 2008). A schematic competitive dialogue procedure is shown in Figure 1.

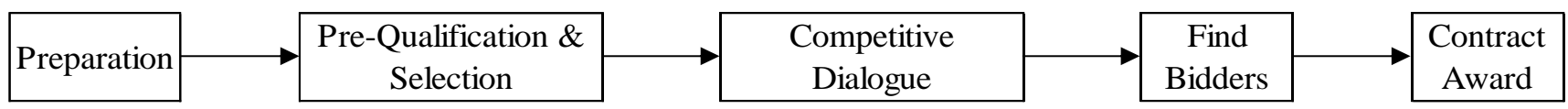

Figure 1. A competitive dialogue procedure

Once this stage is concluded the selected proponents are required to submit the final bid but before the preferred bidder is chosen the proponents must clarify and specify their final bidding documents. In specific circumstances if the contracting authority is faced with difficulties in selecting a final bidder to execute the contract, a competitive negotiated procedure would then be undertaken.

Depending on the type of the PPP project, several agreements may be negotiated to fulfil the required objectives. For instance, the agreement that determines the responsibilities and obligations of the successful proponent to deliver the design and construction, the management and operation agreement, project commissioning agreement etc. 


\subsubsection{Value for Money Assessment (VFM)}

Value for Money (VFM) assessment is considered an important component for the public sector in terms of knowing the expected benefits and costs of the delivered service. Once the preferred bidder is identified the public sector will request a detailed value for money assessment to confirm that the selected bidder would provide appropriate value to deliver the project. VFM is assessed by comparing the estimated total cost of the preferred bidder with the public sector comparator (PSC). The public sector comparator represents a cost estimate of the public sector to deliver the service within the framework of providing value for taxpayers. During the procurement process there may be specific changes in the output specifications or contract agreements. The cost implication of these changes may affect the PSC which is encouraged to update these implications before making a final comparison with the preferred bidder. The VFM is considered positive when the benefits for delivering the project exceeds the cost. It is important to conduct the most comprehensive assessment in order to satisfy the service requirements. After the VFM is finalized and the procurement conditions are satisfied the public sector client will approve the proposal and let the preferred bidder to prepare the final business case.

\subsubsection{Submission of Final Business Case}

Preparing a detailed final business case is considered a challenging task for the majority of bidders. For this reason an experienced and qualified staff is required. Once the VFM is assessed and the preferred bidder is chosen, the Final Business Case (FBC) must be prepared to obtain the approval from the public authorities. The FBC should demonstrate the final scope and cost as well as the clear objectives and conclusions required to perform the project. The main headings of a good FBC may include but are not limited to (a) executive summary, (b) objectives and specifications of the project, (c) proponent consultation, (d) financial resources and affordability, (e) competitive procurement process, (f) risk identification and risk allocation and (g) contract and payment mechanism. The FBC serves as a supporting document for the public sector to identify the key components that will influence the project delivery. Also, it is helpful for the public sector to indicate the forward plan and monitor the service performance of finalizing the contract with the preferred bidder.

\subsubsection{Commercial Closing and Financial Closing}

After the Final Business Case is completed and approved the contract is awarded to the successful bidder. The anticipated date and the successful bidder who is going to execute the contract must be announced publicly in an efficient and effective manner according to public policy and regulations. 


\subsection{Nature and Scope of PSOS}

Performance-based output specifications (PSOS) have been considered a critical component and an effective mechanism for delivering PPP infrastructure projects. The development of PSOS requires great efforts and technical expertise. Therefore, to understand the nature and scope of output specifications, a comparison between the traditional procurement and PPP procurement approach must be carried out. The traditional approach for delivering large and complex infrastructure projects (i.e.,DBB) is based on detailed input-based technical specifications where the public sector determines the required service and takes full responsibility from the conceptual design to the final delivery of the service ensuring that it is performed correctly in accordance with the technical standards.

On the other side, in comparison with input-based technical specifications the performance-based PSOS in the PPP approach is more difficult to stipulate. Whereas, the input-based technical specifications in the traditional delivery method serves only a supplementary prescription of the design to the detailed design drawings. Therefore, the performance-based output specifications needs to provide an overarching description of the facility to be built by the preferred proponent. As a result, the scope of PSOS is much wider and more abstract than the input-based technical specifications. In addition, in a typical PPP project the PSOS covers not only the state of the built facility but also the performance specification of the operation, maintenance and rehabilitation. In a typical DBFOM project, the public sector specifically identifies the type and level of service and leaves the successful bidder to perform and deliver the service. PSOS is an essential part of the procurement process. Therefore, it must clearly state and meet the public sector requirements. In addition, the PSOS should define the criteria of the project in order to achieve the maximum level of quality. These criteria must be satisfied by the bidding proponents in terms of developing and implementing innovative and cost-effective solutions within the public sector budget which would increase the flexibility and the service delivery performance.

Through the implementation of PSOS, the private sector undertakes the responsibility and risk to decide how it will provide the required service. The successful development of PSOS is related with the involvement of all project proponents throughout the whole life-cycle process of a PPP project, from the procurement stage to the construction, operation and maintenance stage and even to the handover stage. Public-private partnerships require the private sector to construct and operate the facility through the concession term by meeting and executing the PSOS requirements as specified in the contract documents and transfer the facility back to the public sector when the contract expires. PSOS must be well prepared and clearly address the scope and objectives of the asset that has to be performed. Javed, Lam, and Chan (2013) stated that PSOS contains aspirations, purposes, scope, performance target, and also demonstrates 
the standard of compliance, constraints and risk allocation. The overall performance target of drafting and executing robust PSOS is to achieve the performance quality and provide benefits for the end users.

Specifications for the project can be developed either in prescriptive (input-based) terms or performancebased output terms or a combination of both depending on the nature and complexity of the facility. But with the continuous advancement of technology in the construction industry, there has been a change to use PSOS for PPP projects rather than input-based or prescriptive technical specifications used in traditional projects. PSOS should be prepared in conjunction with the standard manuals provided form governmental agencies. Most of the international PPP large-scale infrastructure projects have been using outputs rather than inputs leading to increase the effectiveness and performance of the asset as well as reducing the lifecycle cost.

\subsection{Guiding Principles of PSOS}

This subsection discusses the guiding principles related to the development of performance-based PSOS. These principles can be used for information purposes to help and guide the specification writers to develop PSOS.

\subsubsection{Statement of Client Requirements}

Performance-based PSOS are closely related with the statement of client requirements. By using a clear enough and well defined PSOS the public sector client determines what level of service it wants and leave sufficient room for the private sector to innovate. Therefore, the PSOS act as a brief for performing PPP infrastructure projects. For some particular projects the PSOS can be very complicated which can make the private sector unable to deliver the public infrastructure services. These issues can be avoided by carefully reviewing the PSOS during the bidding process to ensure that it is clearly constructed and the performance criteria are measurable.

Sometimes the development of PSOS requires technical skills and professional expertise which have a broad range of experience in large-scale PPP projects. In order to fulfill the client requirements the PSOS needs to be compatible with the other contract documents. But to successfully achieve the performance standards the public sector should improve the quality of PSOS and reduce the subjective elements that may cause ineffectiveness of the project in the later operating phase. This can be performed by adopting comprehensive performance measures which will help to clearly identify the performance target. Also, it is well accepted from public and private sector managers that the performance measures associated with the development of PSOS must be well identified to meet the client requirements. The elements of PSOS 
should be evaluated in conjunction with the involved proponents to accomplish the specified objectives and meet client requirements.

For various PPP infrastructure projects, different PSOS are used. Some procurement agencies think that a standardized PSOS for PPP projects is ineffective. Some others are putting new efforts to have a standardized PSOS for PPPs which will be relatively more effective and produce more benefits. However, the variability of using comprehensive PSOS for specific projects, is proven to be helpful for the private sector to provide innovative alternatives and meanwhile for the public sector to achieve the desired outcomes. The PSOS should be well prepared by clearly understanding the design and construction requirements integrated with life-cycle approach. This combination is based on a good and effective communication network between public sector, private sector and even the end users.

\subsubsection{Achieving Value for Money (VFM)}

In the PPP infrastructure approach, the achievement of Value for Money (VFM) is considered of great importance for both public and private sector benefits. According to Infrastructure Ontario (IO), value for money consists of developing and comparing the estimated total costs of delivering a public infrastructure project using the PPP delivery method to the costs of delivering the similar infrastructure project with identical specifications using the traditional delivery method. The difference between the estimated project costs under each method is referred as the VFM. The comparison of the project costs should demonstrate positive value for money in order to successfully meet the public and private sector requirements.

The performance-based PSOS are closely related with VFM benefits, expressed in dollars, for both public and private sector parties. Therefore developing clear enough and constructive PSOS will help the public sector to monitor the performance of the private sector and to ensure that positive VFM is achieved. Also, clearly defined PSOS will provide greater value for the private sector to determine the best methodology to meet the design and performance requirements through the implementation of cost-effective and innovative solutions within the public sector budget. Through the development of PSOS the public sector evaluates and provides the necessary budget required to deliver the project. Accordingly the internal and external costs associated with an efficient risk allocation should be evaluated in order to obtain a comprehensive and accurate VFM assessment. During the bidding process the private sector must carefully analyze the PSOS to determine whether the delivery of the infrastructure project is worth in terms of profit margins. Aside from this implication, the investigation of PSOS is essentially critical to avoid later disputes during the operation phase of the project.

The competitive bidding process and private sector innovation are also considered important components to assess value for money measures. In a competitive bidding environment the private sector will provide 
all the necessary tools and techniques to implement and improve the technical and design specifications related to the project, to ensure that it will meet the output terms specified by the public sector. However, a small number of competitive proponents will narrow the VFM assessment. It is proven that the smaller the number of competitors the more difficult is to achieve VFM in PPP infrastructure projects because the private sector does not need to put much effort to win the contract. The private sector innovation is another VFM measure that relies on the ability of the private party to enhance VFM through the execution of efficient and practical innovative solutions according to the outputs specified earlier in the contract documents. All of these VFM measures are considered the main key components to achieve VFM benefits by involving the private sector to implement comprehensive PSOS and increase the effectiveness of the PPP infrastructure projects.

\subsubsection{Innovation}

The innovation approach has been considered the main promoter influencing the development of PPP projects. Respectively, Infrastructure Ontario, 2007 and Partnerships BC, 2011 stated that the innovation concept is closely related with three main components including: (a) the financial incentives used in the PPP model, (b) the performance-based PSOS developed in the earlier procurement stage and (c) the common cooperation between the public and private sector. The integration of these components into the PPP infrastructure project will reduce the life-cycle cost and enhance the quality of the project.

As a primary incentive for economic development, innovation has been defined as a consistent strategy leading to new ideas or best practices applied to deliver the public infrastructure projects. According to Infrastructure Ontario, the development and implementation of PPP infrastructure projects, using the Design-Build-Finance-Operate and Maintain as a primary model, is being considered the main indicator influencing the innovation approach. Therefore, it is understandable that the PSOS remains the main promoter supporting the innovation in the PPP model. Through the identification and development of PSOS during the bidding process, the private sector has more flexibility to propose potential innovative solutions ensuring that the design and functional requirements will be performed in an efficient and effective manner meeting the client requirements.

In general, PSOS forms the core of innovation. From this point of view the innovations must fit within the framework of PSOS. In Ontario, the majority of PPP infrastructure projects are procured using the Alternative Financing and Procurement (AFP) model. Typically, using the AFP model Infrastructure Ontario (IO) works closely with the provincial ministries to produce suitable PSOS that define their end product and leave the private sector to provide innovative ideas associated with high quality and low cost (Infrastructure Ontario, 2007). However, before entering the negotiation process Infrastructure Ontario and 
the client ministry evaluate all proposals submitted from the qualified bidders. During this stage the innovations related to design and construction methods may be introduced and negotiated between IO and the preferred bidder using the value engineering technique that would help to determine the overall cost and quality of the project.

Delivering public infrastructure based on standard and technical specifications is not a difficult process, but proposing and integrating innovative solutions into the project constraints is a challenging task. Therefore, the public and private sector must deeply collaborate with each other to ensure that the innovations will occur and PSOS will be incorporated in a most efficient way. Usually, the innovation incentives are related to the proponent preferences. Consequently, the performance standards of the project must allow sufficient room for the private sector to provide appropriate innovations to complete the project and satisfy the public sector preferences. It must also be noted that PSOS enhances the uniformity of innovation and increases the overall performance of the project measured by cost and quality.

\subsubsection{Risk Allocation and Risk Transfer}

Before entering the contract agreement the public sector needs to assess the critical risk factors that may have a significant impact on the successful delivery of the PPP project. It is essential that these risk issues are identified earlier during the procurement stage to ensure that the appropriate risk allocation and the best party to manage the associated risks is identified. Risk allocation and risk transfer in PPP infrastructure projects consist of one of the main critical components to delivering successful public infrastructure. The public sector has to ensure that the risk allocation in financial terms is properly translated into the PSOS. The public sector is also required to identify which risks have to be retained and which have to be transferred to the private sector. For this reason the overall risk assessment, together with the associated costs and who is the party best able to manage them, needs to be evaluated.

In order to prepare and draft a good set of PSOS the risk should be appropriately allocated and evaluated to avoid issues in the later operating phase. The effective risk allocation is related to the cost-effective mechanism undertaken between the public and the private sector. The appropriate implementation of this mechanism would reduce the cost of construction and operation for public infrastructure projects and meanwhile will enhance the VFM. In PPP infrastructure projects, the degree of risk allocation to the private sector will be determined based on the nature and the complexity of the project. Therefore, the PSOS must be well established in order to facilitate clear objectives for the private sector in terms of the level of service that needs to be performed. The primary objectives of transferring risks from the public to the private sector are:

- To reduce the overall life-cycle cost by allocating risk to the party best able to manage it. 
- To provide sufficient incentive to the private sector to deliver the project on time and within budget based on the performance-based PSOS.

- To improve the performance quality of the project based on the application of the best innovative techniques and methods.

- To ensure that the performance-based PSOS are executed in an efficient and cost controlled manner and the successful delivery is achieved.

Typically, in a PPP infrastructure project a risk management plan should be developed in order to identify and analyze the potential risks and implementing responses which reduce their impact. The risk management plan will be helpful for both public and private sectors. On one side through the implementation of a risk management plan the public sector will know of what risks it has to retain and how they affect the delivering outputs. On the other side the management plan will help the private sector to identify the transferred risks and to propose appropriate measures to treat and mitigate the likelihood of occurrence in the PPP project. Each party should analyze and treat the risks in the most cost-effective way to achieve economically optimum solutions. Hence, the performance-based PSOS needs to be written clearly considering the overall life-cycle cost rather than capital cost alone to ensure that the optimal risk allocation and risk transfer is achieved.

\subsubsection{Life-Cycle Asset Performance}

In PPP infrastructure projects the life-cycle performance of the asset is one of the key attributes that the public and private sectors should bear in mind. In order to successfully achieve the project objectives it is imperative to prepare constructive and strong PSOS. The PSOS should be aligned with the project requirements to ensure that the overall life-cycle asset performance is achieved and the project objectives are satisfied. Very detailed and prescriptive specifications would prevent the private sector to conduct innovations and to enhance the appropriate risk allocation. Regardless of the type of the asset to be delivered, the PSOS should clearly describe the required scope, the functional and design parameters, financial and operational incentives to meet the client requirements, and achieve the performance target. For instance, considering a transportation public infrastructure asset, the public sector can specify the minimum output requirements such as the traffic volume capacity or traffic signals at the main intersections to be designed and built according to technical standards and specifications.

Efficient risk allocation and well execution of PSOS are fundamental to fulfil the life-cycle requirements for the PPP projects and to successfully deliver the desired end product. Typically, PPP infrastructure projects involve a concession period of 20-30 years. During this period variation changes in PSOS may occur which may bring substantial cost impacts. Many public and private agencies believe that one of the 
major risks due to the long term nature of PPP projects is variability of PSOS. Over and over, these changes will affect the construction and operational phase and will reduce the life-cycle asset performance. The majority of PPP infrastructure projects are exposed to foster ineffective future changes of PSOS. When major changes are likely to occur, a common negotiation between the public and private sectors must be assigned in order to emphasize the responsible party for spending extra time and paying extra costs. Therefore, to avoid these implications a well drafted PSOS must be developed and implemented throughout the life-cycle of a PPP project.

\subsubsection{Performance Monitoring and Payment Mechanism}

Payment mechanism is a critical factor which has to be carefully applied through the long term PPP contractual arrangements. Usually, in large and complex infrastructure projects the private sector is required to take the responsibility to design, build, finance, operate and maintain the facility based on public sector requirements. Using the performance-based PSOS defined earlier in the RFP contract document, the private sector is assumed to perform the service and get paid based on the asset performance. This means that the public sector does not pay for the asset until it is fully performed. A substantial portion of the cost will be paid by the public sector over the life of the asset. The project performance will be monitored by the public sector and payment will be conducted only if the asset is properly maintained and has performed according to the established specifications.

Based on the capability of the private sector to deliver the required outputs, some PPP infrastructure assets may result in low construction performances. Therefore, as a result the payment mechanism is subjected to the risk of diminutions. Through the monitoring survey techniques the public sector will monitor the asset performance and if the required outputs are successfully delivered the payment will be distributed to the private sector fairly in an efficient way. Performance monitoring is considered a potential mechanism used to ensure that the performance standards are always met and the client requirements are fulfilled (Robinson $\&$ Scott, 2009). Self-monitoring is usually recommended to be undertaken by the private sector itself and based on the achieved continuous performance it is responsible for reporting to the public sector on a monthly or quarterly regular basis. Usually help desks, site visits, management systems and third party audits can be used to monitor the asset performance.

The identification and implementation of Key Performance Indicators (KPI) are vital to assess the required objective through the execution of PSOS. But if the public sector fails to link the payment mechanism with the PSOS reflecting the desired end product, then the private sector will struggle to produce good quality and achieve a high level of performance. In some public infrastructure projects the private sector can be exposed to late delivery of the asset. In this case liquidated damages have to be used in order to avoid the 
impact of construction risks. But the ultimate challenge is the performance of the project before the deadline specified in the project agreement. The early completion of the project will affect the performance quality and increase the operational risks associated with cost implications.

\subsection{Literature Review}

Performance-based output specifications (PSOS) have shown a significant function in the successful delivery of PPP projects. The development of PSOS is initiated in accordance to the performance requirements for a specific project. Whereas the main objective of PSOS is to identify a desired performance target, they do not necessarily provide detailed information on how the performance target is measured. The successful development and implementation of PSOS is fundamental for PPP infrastructure projects. Regardless of the interest in identifying how PSOS influence the PPP projects, still there is an empirical evidence among this subject. Infrastructure Ontario (IO) and other procurement agencies across the province have been playing an important role in developing PSOS for procuring PPPs. The main role was to assist the project owners and private proponents with the preparation of bidding documents and PSOS in particular, ensuring that the design end product is performed with a high quality level. The significance of developing a good set of PSOS and in particular enhancing the current practice of PSOS have been under the attention of many procurement agencies, private authorities and academic critics. Therefore many research studies have been conducted to highlight the need for a good PSOS and to provide better evidences for the procurement agencies to improve their ability in developing robust PSOS.

Akintoye \& Beck (2009), concluded that a good PSOS will clearly specify the client requirements and reduce the possibility of contravention in later project phases. As an integral part of the bidding documents, a PSOS is essentially needed to act as a fundamental design and operational indicator for PPP projects and should form a core section that will help to successfully deliver the long term services (Javed, Lam, \& Zou, 2013).

Based on a structured research interview study of PSOS for PPPs in Australia, Javed, Lam \& Chan (2013), pointed out the significance of PSOS in delivering PPP projects. For hospital PPP projects, he emphasized that if specifications are too prescriptive they would not allow innovation and appropriate risk transfer to the private sector. So specifying outputs rather than inputs of the project would provide flexibility to the practitioners in the private sector including facility managers.

Moreover predicting every possible change in a PPP contract in order to reach a final project agreement between project proponents is a difficult process, but indicating its significance in PSOS would be a necessity. One of the major risks in PPP infrastructure projects is the variability of PSOS. Such changes may occur in various stages of an infrastructure project. Proposed variations by the clients can affect the 
responsible construction contractor, by spending more time and paying extra cost. In this case the client and the contractor have to find an effective negotiable way to achieve a reasonable mutual agreement that would satisfy both parties' outcomes.

Drafting a comprehensive and an effective PSOS to fulfil the project requirements and achieved the desired outcomes is a challenging process which require time, effort and expertize and this investment is quantitatively considered of great importance for delivering the PPP projects (Javed, Lam, \& Chan, 2013). Settled output-based specifications will be useful for the public sector to clearly articulate its needs and expectations early in the planning process and for the private sector to provide innovative solutions to satisfy the public authority needs

Himmel (2015), found that PSOS are closely related to innovation and he concluded that the innovation must fit within the framework of PSOS through a PPP project. Furthermore, he pointed out that the innovative thoughts related to the design and construction may be included in the PSOS framework. The PSOS are considered to be conducive by incorporating new performance measures or evaluation criteria.

PSOS can be too generic if the private sector does not understand clearly what would be the expected outcomes from a particular project. Implementation of PSOS by the private sector should be well performed during the design, construction and operation phases and unnecessary specifications that would impact the delivery performance should be reduced. However these issues can be avoided earlier from the carefully review of PSOS during the bidding process. The main proponents should put more efforts to review and enhance the proposed PSOS in detail before the final draft take place. If these issues are not avoidable and are still present, they also may result in inappropriate risk allocation which can cause deficiencies and inability of the private sector to deliver the project.

The PSOS is essentially a brief for PPP projects. It is considered a core element to define the public authority requirements in order to reach a high level of service in a PPP project. The PSOS is very helpful for the bidders to prepare their proposals and it is used as a key mechanism for the invitation to negotiate documentation (The Scottish Government, 2004).

The more conducive the PSOS, the better the bidding process will be, the higher the level of innovation will be provided by the private sector (Russell, Tawiah, \& Zoysa, 2006). The PSOS shift the responsibility for the complexities associated with the design and construction stages to private sector experts by providing a significant impact on PPP projects (PPP Canada, 2014). Additionally the PSOS enforces the public sector to clearly articulate its needs and expectations of the end product early in the planning process. On one hand changing the project requirements from one of perspective detail to that of a broader outcome, 
will lead to the private sector more flexibility to develop and provide innovative solutions. On the other hand the innovative solutions can increase the Value for Money (VFM) benefits of a PPP model.

A good PSOS is of great importance and critical for PPP projects, but writing a suitable and effective output specification is a very skillful and difficult job (Javed, Lam, \& Chan, 2014). The components of PSOS are very unique for a specific project. Therefore, it is ineffective to use an output specification for all type of PPP projects. By using a clear enough and well organized PSOS, the value for money, risk allocation and risk transfer can be evaluated and leading more room to encourage design and construction innovation for private sector. The review of the above literature indicate some important tasks on developing and drafting a good PSOS. Apparently, some authors have emphasized the significance of PSOS and some others have pointed out the difficulties on developing a high-quality PSOS. However, the current literature does not provide a specific methodology to identify the qualities for a good PSOS. Therefore these evidences must be emphasized and organized in such a way to help the PPP agencies for improving the current practice of PSOS. Infrastructure Ontario, Partnerships BC, Government of Alberta and many other procurement agencies have been implementing a significant number of performance measures to ensure that a positive PSOS is delivered. These functionalities are observed in many PPP infrastructure projects including: highways, hospitals, schools, transit systems etc. A good PSOS should reflect the future needs and provide value benefits for the end user. In order to develop a comprehensive PSOS, a system engineering approach must be followed. Following the methodology that the system engineering approach provides, would be very helpful for the procurement agencies to develop a high quality PSOS and encourage the private sector to effectively meet the client needs. 


\section{The Proposed Framework}

This section/chapter discusses the proposed framework for developing a performance-based PSOS of a PPP infrastructure project. Following the general principles of systems engineering, the proposed framework starts from the client needs through functional decomposition to the specifications and culminates with the determination of performance measures, targeted level of services, performance measurement and monitoring, and performance-based payment mechanisms.

\subsection{A Hierarchy of System Performance}

PPP infrastructure projects can be considered as a complex engineering system composed of a systematic combination of performance measures, integrated in such a manner to fulfil the designated need. The ultimate objective of a system performance hierarchy is not only related with the integration of the performance measures, but also with the interrelationship of the components among the proposed system. So by performing such objectives the performance target can be realized (Blanchard, 2008).

Usually the system is constructed in a systematic hierarchical level divided into subsystems associated with related components. For instance, a bridge may be included in a highway which is part of a transportation facility, which is operated in a specific geographical area, which is part of a province and so on so forth. Therefore, the system being addressed is highly influenced by the performance of a higher-level system (Blanchard, 2008). A simplified conceptual framework of an engineering system including the external constraints and the required mechanisms necessary to realize the desired outcome is presented in Figure 2. 


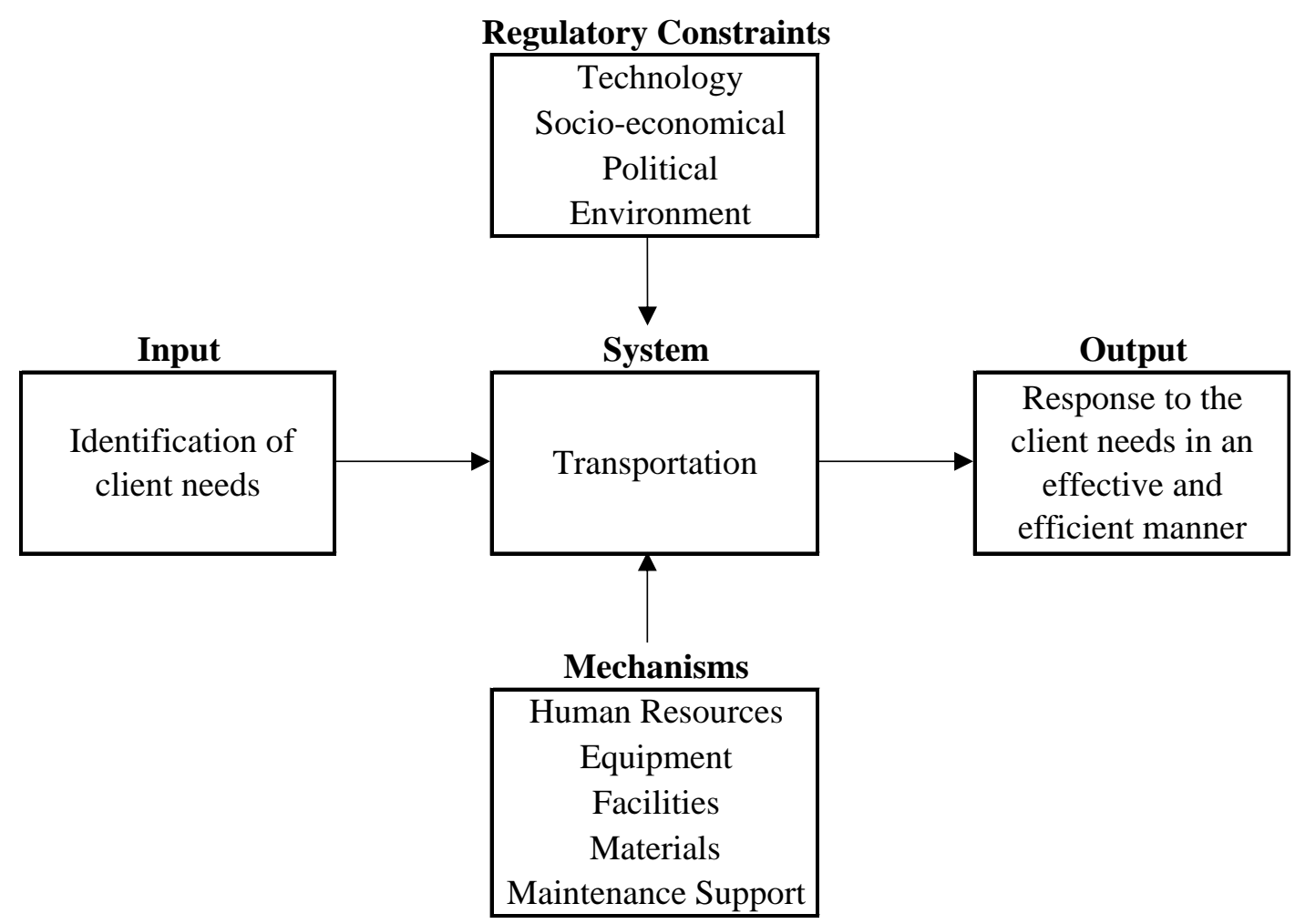

Figure 2. A simplified conceptual framework of a transportation engineering system

In order to produce a high quality PSOS for infrastructure projects, the potential performance measures must cover the state of the built facilities not the performance of project management. For example, cost is a performance of the facility, but cost overrun is a performance measure for the project management. Therefore, in this case the cost needs to be considered. The most effective and efficient performances considered in the hierarchical development of PSOS of PPP infrastructure projects can be divided in three levels. The first level includes the performance of the life-cycle such as: design, construction, operation, maintenance and rehabilitation, and even the hand back. In terms of performance measure, which aligns with the second level of the hierarchy, each life-cycle performance is decomposed to specific measures. For instance, the performance measures being addressed to design are, but not limited to functionality, lifecycle cost, safety, sustainability, etc. Accordingly, there is an ongoing and iterative process which further decomposes the performance in different levels throughout the implementation of performance measures. This process is then concluded at the culminated target level of services and measurement. The performance measures associated with the life-cycle cost are the capital expenditures and operation and maintenance costs. As an example, in transportation infrastructure, functionality is measured by numerous performance measures such as International Roughness Index (IRI), Pavement Condition Index (PCI) etc. Through the same methodology, other performance measures could be evaluated as shown in the proposed generic framework in Figure 3. 


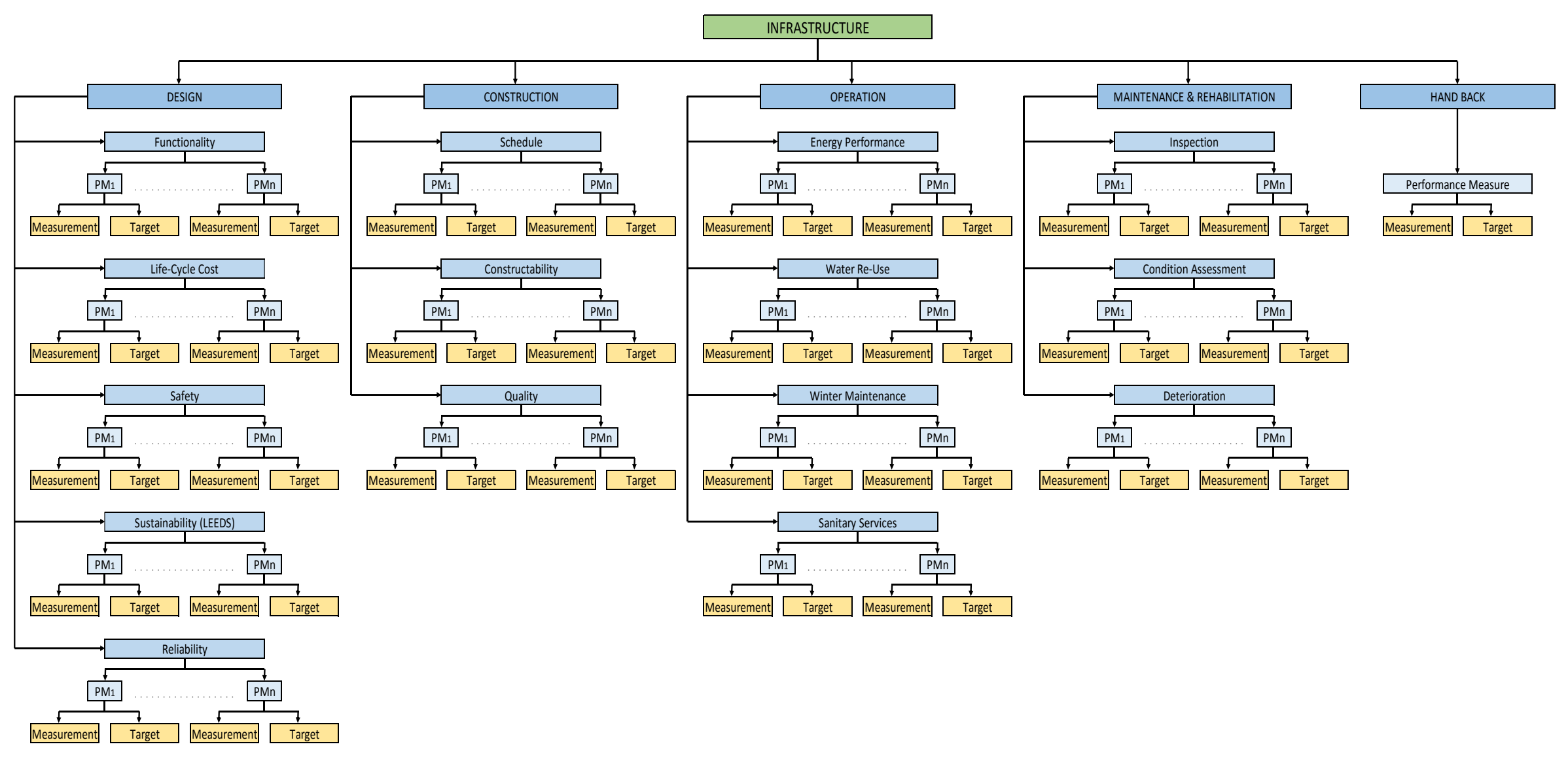

Figure 3. The proposed framework for developing PSOS 
Subsequently, the performance may be decomposed following a performance breakdown structure ensuring that the overall life-cycle performance of the system is measured in a systematic way and the performance target is significantly achieved. However, it should be noted that different facilities have different performance measures. Therefore, the PSOS writers have to carefully evaluate the performance measures in accordance to the nature of the built facility.

The most critical components of PSOS must be clearly emphasized and interpreted in order to provide a high quality designed end product. Through the development of a systematic performance hierarchy the most critical components of a good PSOS are:

1) A complete (yet mutually exclusive) hierarchy of performance breakdown.

2) Clearly defined performance measures.

3) Completely implementable performance measurement methods.

4) A firm and economically justified performance target.

From the system engineering management perspective, the process of the system engineering commences with the identification of client needs to the delivery of the product which satisfies these needs. In addition, the hierarchy is developed through the accomplishment of client needs through functional decomposition to the specifications and culminates with the determination of performance measures, targeted level of services, performance measurement and monitoring, and performance-based payment mechanisms.

Based on the above explanation it must be emphasized that the primary mechanism in developing constructive PSOS is to understand the client needs or client requirements. To ensure that the designed end product would be achieved according to the required standards in a cost-effective manner the identification of the client needs must be clearly presented and evaluated in specific qualitative and quantitative terms. From the public sector point of view the requirement for identifying the need seems to be self-evident, meaning that the efforts to design the specific product are initiated as a result of personal interest without being adequately defined (Blanchard, 2008). However, there are some instances in which the proponent does not really understand the client's real need after they have read the PSOS. As a result it is not uncommon that an undesired product may be designed without accomplishing the client needs. It should be highlighted that in compliance with the PSOS the main objective is to identify what is required rather than how it is going to be performed. The top-down approach is relatively required in order to achieve the desired end product by considering the system as a whole.

Having a good understanding of the system environment together with their associated components mentioned above, it is potentially comprehensible that the overall target of the PPP projects is closely 
related with the development of PSOS, results from the interaction of project components associated with their respective attributes. This mutual relationship will be helpful for the public sector to fulfil the required objectives and at the same time would provide more flexibility to the private sector to prepare design and construction innovations, and achieving VFM benefits.

As noted in the aforementioned paragraphs, the top-down approach is considered a suitable technique reflecting the development of PSOS for PPP infrastructure projects. In a given system engineering framework the input-based technical specifications are usually prepared at the end of the detailed designed phase, while the performance-based PSOS are established on the basis of a reference design, which usually consists of the conceptual design. Whereas, the input-based technical specifications are often developed in a bottom-up approach, the performance-based PSOS must be developed following a top-down approach, meaning that the client needs must be well captured and fully understood. Considering the top-down approach and based on the system engineering theory, a systematic hierarchical process related to the development of PSOS in PPP infrastructure projects is established as shown in Figure 4.

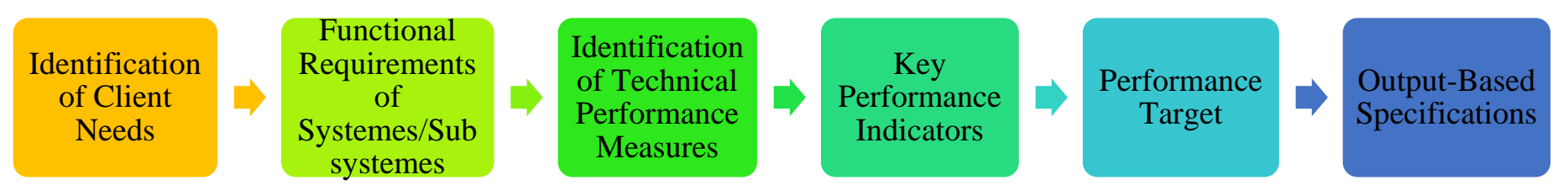

Figure 4. The top-down approach for the development of performance-based PSOS in PPP projects

Typically, a good performance-based output specification should:

- Provide a clear objective to the client ensuring that the client requirements are properly measured and these requirements must be reflected to the public community.

- Provide sufficient room and flexibility for the private sector or general contractor to achieve the performance target to a high-level of quality through implementation of innovative and cost-effective solutions.

- Allow the proposals submitted by the qualified proponents to be evaluated according to the criteria specified in the contract.

- Identify the most critical issues of the facility that will reflect the performance monitoring linked with the payment mechanism.

- Allocate and accommodate the internal and external constraints in accordance with performance measures and policies.

- Provide a suitable environment to ensure the coordination between design, construction, operation and life-cycle maintenance. 


\section{Case Studies}

So far, the development of performance-based PSOS have been discussed in general terms without looking at specific project outputs. In Ontario, a significant number of large-scale infrastructure projects are being procured under the PPP approach. It has been a primary objective to involve one of those infrastructure projects in the report, but due to the absence of information about the output specifications provided by Infrastructure Ontario, it was difficult to figure out a suitable project. Therefore, based on the complexity, substantial impact and the level of performance two projects were selected as case studies in order to analyze and evaluate PSOS and better understand their implications: Sea-to-Sky Highway Improvement Project in British Colombia and Anthony Henday Drive Southeast Leg Ring Road in Alberta. Reliable information regarding each infrastructure project was gathered through the documents provided by Partnerships BC and Alberta Ministry of Transportation websites respectively. The two selected infrastructure projects were considered as of great importance in terms of accommodating population growth and supporting economic development across the province. In order to identify the similarities and differences of each project, the respective attributes are shown in Table 1.

Table 1. The respective attributes for each infrastructure project.

\begin{tabular}{lcc}
\hline Project Attributes & Sea-to-Sky & $\begin{array}{c}\text { Southeast Anthony } \\
\text { Henday Drive }\end{array}$ \\
\hline Delivery Method & DBFO & DBFO \\
Capital Cost & $\$ 600$ million & $\$ 493$ million \\
RFQ & 2004 & 2003 \\
RFP & 2005 & 2004 \\
Shortlist Proponents & 3 & 3 \\
Long-term Contract Period & 25 years & 30 years \\
Anticipated Date & 2005 & 2004 \\
Completion Date & 2009 & 2007 \\
\hline
\end{tabular}




\subsection{The Sea-to-Sky Highway Improvement Project}

The Sea-to-Sky highway is defined as a 95- kilometer long section of Highway 99 from West Vancouver to Whistler. Located in the province of British Columbia, the highway is exposed to many construction, engineering and traffic management challenges. In 2004 the British Columbia`s Ministry of Transportation decided to make improvements to the highway of approximately $\$ 600$ million in order to enhance safety, reliability and capacity. The design and construction of approximately two-thirds of the capital expenditure improvements were delivered by using the DBFO delivery model, while one-third was delivered by the province through separate Design-Build (DB) contracts. The purpose of using DB contracts was to mitigate the schedule risk of the project. These improvements include highway widening and straightening, additional passing lanes, sightlines and other design and innovation measures to reduce hazards, shorten travel times and increase capacity of the highway. The proposed improvements were expected to fulfill the Ministry of Transportation long-term objectives for the highway in terms of accommodating population growth, providing economic development through the province and increasing demand for resident and visitor traveling. In addition, the Sea-to-Sky Highway Improvement Project created over 6,000 new jobs throughout the province and meanwhile will contribute $\$ 300$ million to provincial GDP over the period of 2010 to 2025 . The overall benefits to the province were estimated to be in the range of 15 to 20 percent through the successful execution of the project (Partnerships BC, 2006).

The Sea-to-Sky highway improvement project is being procured using a 25 -year performance based Design-Build-Finance-Operate (DBFO) public-private partnership contract between British Colombia's Ministry of Transportation and S2S Transportation Group. Under this contract the private sector (S2S Transportation Group) was responsible to design and construct highway improvements and to operate and maintain the infrastructure project based on the technical and performance-based PSOS specified in the contract. Having a potential economic and social impact to the other communities and resources of Lions Bay, Furry Creek, Squamish, Whistler, Pemberton and Mount Currie the expected ultimate improvements for each section through the implementation and execution of DBFO contract as well as the added value beyond expected improvements are shown in Table 2. As a result the overall improvement along the concession period includes $80 \mathrm{~km}$ of additional passing lanes and $36 \mathrm{~km}$ of additional median barriers. Furthermore, highway straightening, wider shoulders and enhanced methods of minimizing rock fall debris were considered as additional highway improvements that will impact safety, capacity and reliability along the corridor. 
Table 2. Baseline improvements and expected value for each section of the infrastructure project.

\begin{tabular}{|c|c|}
\hline $\begin{array}{c}\text { Baseline improvements for each section of the Sea- } \\
\text { to-Sky highway project }\end{array}$ & $\begin{array}{l}\text { Added value beyond expected baseline } \\
\text { improvements }\end{array}$ \\
\hline Squamish to Whistler & $\begin{array}{l}60 \mathrm{~km} \text { baseline passing lanes and } 20 \mathrm{~km} \text { additional } \\
\text { passing lanes (33\% more). }\end{array}$ \\
\hline $\begin{array}{l}\text { 3-lanes throughout this section, including improved two- } \\
\text { lane sections and alternating passing opportunities } \\
\text { provided by the third lane. }\end{array}$ & $\begin{array}{l}20 \mathrm{~km} \text { baseline median barrier and } 16 \mathrm{~km} \text { additional } \\
\text { median barrier ( } 80 \% \text { more })\end{array}$ \\
\hline North of Murrin Park through Squamish & \multirow{3}{*}{$\begin{array}{l}\text { Additional highly reflective pavement markings where } \\
\text { they are most needed to enhance safety. } \\
44 \mathrm{~km} \text { baseline shoulder and centre-line rumble strips } \\
\text { and } 30 \mathrm{~km} \text { additional shoulder and centre-line rumble } \\
\text { strips where most effective throughout the corridor } \\
(68 \% \text { more). }\end{array}$} \\
\hline $\begin{array}{l}\text { 4-lane divided highway. This section will include } \\
\text { median barriers throughout, including the addition of } \\
\text { urban design features to the median within Squamish. }\end{array}$ & \\
\hline North of Lions Bay to Murrin Park & \\
\hline $\begin{array}{l}2,3 \text {, and } 4 \text { lane sections. About half of this section } \\
\text { includes improved two lanes. The remaining sections } \\
\text { would provide additional passing opportunities of } 3 \text { or }\end{array}$ & \multirow{6}{*}{$\begin{array}{l}\text { Improved lighting and roadside reflectors throughout } \\
\text { the corridor for additional safety. } \\
\text { Improved earthquake resistance and lighting on } \\
\text { bridges. } \\
58 \mathrm{~km} \text { baseline wider shoulders and } 10 \mathrm{~km} \text { additional } \\
\text { wider shoulders for improved safety and } \\
\text { accommodation of cyclists (17\% more). } \\
\text { Improved rock fall and debris catchment } \\
\text { Additional highway straightening and improved } \\
\text { sightlines. }\end{array}$} \\
\hline $\begin{array}{l}4 \text { lanes located for maximum safety benefits. Those } \\
\text { sections that are } 4 \text { lanes will include a median barrier to }\end{array}$ & \\
\hline $\begin{array}{l}\text { prevent cross-over accidents. Sections adjacent to } \\
\text { Murrin Park and within the community of Britannia } \\
\text { Beach will include improved } 2 \text { lane sections, consistent } \\
\text { with community input at the pre-design stage. In Furry }\end{array}$ & \\
\hline & \\
\hline & \\
\hline West Vancouver to Lions Bay & \\
\hline \multirow[t]{2}{*}{$\begin{array}{l}\text { 4-lane sections with continuous median barrier, } \\
\text { including straightening, widening and improved } \\
\text { sightlines. }\end{array}$} & $\begin{array}{l}\text { Additional enforcement and emergency response. } \\
\text { Safer and more effective intersections, particularly in } \\
\text { urban settings. }\end{array}$ \\
\hline & $\begin{array}{l}\text { Improved highway maintenance response to weather } \\
\text { conditions. }\end{array}$ \\
\hline
\end{tabular}

\subsection{Performance-Based PSOS of Sea-to-Sky Improvement Project}

Performance-based PSOS for the Sea-to-Sky Highway project were developed in accordance with technical and design standards to ensure that the minimum performance requirements were met. The design and construction PSOS and traffic management PSOS were carefully identified and elaborated through a detailed review of procurement documents and in particular of Schedule 5. Meanwhile, the operation, maintenance and rehabilitation (OMR) PSOS were evaluated by reviewing the similar documents with a primary focus on Schedule 6. Based on the technical performance measures specified in the contract, the concessionaire was encouraged to design, construct, maintain and operate the project facilities, the site and 
the adjacent areas with the goal of providing a quality end product that meets the client's and the end user's needs by adopting innovative and cost-effective solutions. Throughout the successful implementation of PSOS by the concessionaire over the long-term concession the main objective was (Partnerships BC, 2006):

- To provide safety, reliability and capacity improvements.

- To minimize traffic disruption, maximize predictability and to complete the project on time and on budget.

- To enable the Province and other Governmental Authorities to fulfil its and their statutory duties, functions and responsibilities.

- To minimize the occurrence of accidents as well as the risk of damage and destruction to third party property.

- To enable the standards of reliability, serviceability, accessibility, maintainability, quality control and assurance to be achieved in compliance with the contract documents.

- To meet and achieve the environmental objectives and to mitigate the environmental issues.

- To achieve a high level of standard in the appearance and aesthetic quality of the project facilities, the site and the adjacent areas.

Taking into account the new highway infrastructure project, the performance-based PSOS have been clearly identified and formulated in such a way to fulfil the goals of the project including design and construction requirements, operational efficiency, and providing value for money to the taxpayers. A conceptual framework of performance-based PSOS including design and construction output specifications, traffic management output specifications, operation, maintenance and rehabilitation output specifications is presented in Table 3. 
Table 3. A conceptual framework of performance-based PSOS for the Sea-to-Sky highway improvement project

\begin{tabular}{|c|c|c|c|c|}
\hline \multicolumn{5}{|c|}{ Design and Construction Output Specifications } \\
\hline $\begin{array}{c}\text { Highway Design } \\
\text { Requirements }\end{array}$ & $\begin{array}{c}\text { Pavement } \\
\text { Specifications }\end{array}$ & $\begin{array}{c}\text { Structural Specifications for } \\
\text { Bridges }\end{array}$ & Geotechnical Specifications & $\begin{array}{l}\text { Electrical, Signals and } \\
\text { Lighting Specifications }\end{array}$ \\
\hline $\begin{array}{l}\text { Horizontal and } \\
\text { vertical curves, } \\
\text { stopping sight } \\
\text { distance, paved } \\
\text { shoulder width, } \\
\text { median and roadside } \\
\text { barriers, intersection } \\
\text { and access treatment } \\
\text { etc. }\end{array}$ & $\begin{array}{l}\text { Design methodology } \\
\text { including design criteria, } \\
\text { physical and } \\
\text { performance } \\
\text { requirements. Pavement } \\
\text { construction. Recycling } \\
\text { of asphalt pavement and } \\
\text { granular road materials }\end{array}$ & $\begin{array}{l}\text { Structural design criteria, design } \\
\text { codes for new and existing } \\
\text { structures, structural } \\
\text { performance measures (design } \\
\text { life, serviceability, durability), } \\
\text { prestressed R/C members, } \\
\text { foundation, excavation and } \\
\text { backfill, structural steel work } \\
\text { etc. }\end{array}$ & $\begin{array}{l}\text { Geotechnical design criteria } \\
\text { (sesmic design, stability of } \\
\text { slopes, shallow and deep } \\
\text { foundations design, settlement } \\
\text { analysis, rock slopes, internal } \\
\text { and external stability of } \\
\text { Mechanically Stabilized Earth } \\
\text { Wall), special design provisions } \\
\text { for additional structural systems, } \\
\text { geotechnical investigations and } \\
\text { baseline assumptions. }\end{array}$ & $\begin{array}{l}\text { Electrical services, } \\
\text { roadway lighting, traffic } \\
\text { signals to be installed in } \\
\text { accordance with the" } \\
\text { Standard Specifications } \\
\text { for Highway } \\
\text { Construction" developed } \\
\text { by MOT. }\end{array}$ \\
\hline $\begin{array}{c}\text { Drainage } \\
\text { Specifications }\end{array}$ & $\begin{array}{l}\text { Landscape and Site } \\
\text { Restoration }\end{array}$ & $\begin{array}{l}\text { Signing and Pavement } \\
\text { Marking Specifications }\end{array}$ & $\begin{array}{l}\text { Design Submissions, Reviews } \\
\text { and Reports }\end{array}$ & \\
\hline $\begin{array}{l}\text { Surface run-off } \\
\text { flowing design } \\
\text { criteria, } \\
\text { hydrology/hydraulic } \\
\text { design and analysis, } \\
\text { design flow return } \\
\text { periods, Catchbasins, } \\
\text { freeboard } \\
\text { requirements, Scour } \\
\text { depth estimation for } \\
\text { pier and abutment } \\
\text { structures etc. }\end{array}$ & $\begin{array}{l}\text { Detailed landscape and } \\
\text { aesthetic design, } \\
\text { landscape and aesthetic } \\
\text { treatments in linear } \\
\text { areas, planting and } \\
\text { revegetation of roadside } \\
\text { areas, rock cut faces, } \\
\text { sound walls, street } \\
\text { lighting and signs, } \\
\text { concrete barriers, bridge } \\
\text { railing. Retaining walls } \\
\text { and embankments } \\
\text { treatment. Viewpoint } \\
\text { and Pullout Provisions }\end{array}$ & $\begin{array}{l}\text { Static signing, changeable } \\
\text { message sign, pavement } \\
\text { markings and delineators. }\end{array}$ & $\begin{array}{l}\text { Design Management Plan } \\
\text { (design review and audit } \\
\text { schedule, detailed scope for the } \\
\text { safety audit process, drawing } \\
\text { submission schedule, drawing } \\
\text { tree). Design Progress Reports, } \\
\text { drawings and specifications, } \\
\text { record documentation. }\end{array}$ & \\
\hline
\end{tabular}


Traffic Management Output Specifications

\begin{tabular}{|c|c|c|}
\hline $\begin{array}{l}\text { Permitted Traffic Stoppages } \\
\text { and Road Scheduled Closures }\end{array}$ & Traffic Management Plan & $\begin{array}{c}\text { Intelligent Transportation Systems } \\
\text { Technology }\end{array}$ \\
\hline $\begin{array}{l}\text { Traffic control devices, } \\
\text { construction and advisory signs, } \\
\text { concrete roadside barrier, drop- } \\
\text { offs, washroom facilities, } \\
\text { temporary pavement markings }\end{array}$ & $\begin{array}{l}\text { Management plan overview, plan } \\
\text { submission and review, control } \\
\text { plan, implementation plan, } \\
\text { communication and signing plan, } \\
\text { risk assessment plan, public } \\
\text { information plan. }\end{array}$ & $\begin{array}{l}\text { ITS features during construction ( dynamic } \\
\text { massaging sign, portable setups, changeable } \\
\text { messaging sign, centralized control centre) }\end{array}$ \\
\hline
\end{tabular}

Operation and Maintenance Output Specifications

\begin{tabular}{|c|c|c|c|}
\hline $\begin{array}{c}\text { Operation and Maintenance } \\
\text { Requirements }\end{array}$ & Performance system & $\begin{array}{l}\text { Adjustments to Scope of Operation, } \\
\text { Maintenance and Rehabilitation }\end{array}$ & Plans \\
\hline $\begin{array}{l}\text { Pavement rehabilitation design } \\
\text { and construction, winter } \\
\text { maintenance, emergency } \\
\text { response, resources, additional } \\
\text { operation maintenance and } \\
\text { rehabilitation requirements, } \\
\text { traffic management, existing } \\
\text { rock slope monitoring program. }\end{array}$ & $\begin{array}{l}\text { Asset preservation performance } \\
\text { measures ( highway running } \\
\text { surfaces, structures, drainage and } \\
\text { debris control, electrical control } \\
\text { systems, avalanche control } \\
\text { facilities), Operational performance } \\
\text { measures ( preventive action, } \\
\text { quality audit and documentation, } \\
\text { quality policy and record) }\end{array}$ & $\begin{array}{l}\text { Adjustments to southern boundary, MOT } \\
\text { section, olympic periods, side roads. }\end{array}$ & $\begin{array}{l}\text { Quality management plan, } \\
\text { operation and } \\
\text { maintenance management } \\
\text { plan, asset management } \\
\text { plan. }\end{array}$ \\
\hline
\end{tabular}




\subsection{Anthony Henday Drive Southeast Leg Ring Road}

Recently, the province of Alberta is considered one of the fastest growing provinces in Canada with a significant driving force behind the Canadian economic growth. Since 1996, the Calgary-Edmonton corridor has been considered one of the top three growth areas in Canada with a population increase of $12.3 \%$ (Alberta, 2004). Notwithstanding, as a result of the population growth through the province, the need for infrastructure development is increasing.

In the 1970s the Province of Alberta and the city of Edmonton established the Transportation Utility Corridor (UTC) which later was commonly referred to as the Edmonton Ring Road. One of the main transportation infrastructure link under this corridor is the Anthony Henday Drive Southeast Leg Ring Road in the city of Edmonton. The Southeast ring road is considered as Alberta`s first highway procured using a PPP model. Based on the best practices of PPP approach across North America and other developed countries the project was procured using the made-in-Alberta PPP model implemented by Alberta's Government. Using this approach the new infrastructure project includes 11 kilometers of highway with six lanes between Highway 2 and $50^{\text {th }}$ Street and four lanes between $50^{\text {th }}$ Street and Highway 14/216. In addition the project features 20 bridge structures, including 5 interchanges and no traffic lights. The execution of the project provided a new infrastructure model that encourages innovative design, construction and operation efficiency. Meanwhile, the successful delivery of the project helped in reducing traffic congestion and serves as a key transportation link among the city of Edmonton.

In 2004, the Department of Transportation of Alberta issued the Request for Proposal (RFP) in order to identify and select the successful proponent for the design, construction, financing, operation and maintenance of the Southeast ring road and the operation and maintenance of the specified adjacent segments. Following a competitive and transparent bidding process, Access Roads Edmonton Ltd. was selected as the preferred proponent responsible to deliver the project in conformance with the specified requirements and technical performance measures developed for the new infrastructure. Using a 30-year DBFO long-term contract agreement, the contractor was required to perform and deliver the project based on the performance and technical measures ensuring that the overall life-cycle performance is achieved. The total project cost expressed in today's dollars was estimated to be \$493 million. Regardless of what the province had covered on this project, the Government of Canada has contributed roughly $\$ 75$ million to the project through the Canada Strategic Infrastructure Fund (CSIF) (Alberta, 2004). Through the implementation of CSIF the Government of Canada collaborates with provincial, municipal and private sectors to fulfill the strategic infrastructure needs throughout the country and to support PPP infrastructure projects that improve the quality of life and further economic growth. 
In order to fulfil the life-cycle requirements of new infrastructure, the concessionaire was encouraged to successfully perform the project activities based on technical specifications provided in the contract agreement. Therefore, the performance-based PSOS must be well defined in advance to ensure that the flexibility for design and innovation by the private partner is achieved. In other words, the concessionaire must be equipped with sufficient capability to accommodate the project needs and achieve a life-cycle performance through the successful implementation of PSOS. Some of the main features that the new infrastructure supports and the associated benefits are shown in Table 4.

Table 4. General overview of the project scope and the associated benefits of DBFO model.

\begin{tabular}{|c|c|}
\hline General Overview of the Project Scope & Benefits of DBFO model \\
\hline $\begin{array}{l}11 \text { kilometers total length from Highway } 2 \text { to Highway } \\
14 / 216\end{array}$ & $\begin{array}{l}\text { The new infrastructure facility will be built based on full } \\
\text { freeway specifications ( no stop lights) }\end{array}$ \\
\hline $\begin{array}{l}\text { Six lanes between Highway } 2 \text { and } 5 \text { th Street and four } \\
\text { lanes between 50th Street and Highway } 216 / 14\end{array}$ & $\begin{array}{l}\text { Capital costs are fixed and the province is protected from } \\
\text { inflation }\end{array}$ \\
\hline 24 separate bridge structures & $\begin{array}{l}\text { The province is insulated from risks, such as weather delays, } \\
\text { difficult ground conditions, construction defects, etc. }\end{array}$ \\
\hline 124 lane kilometers of road & $\begin{array}{l}\text { The new southeast ring road will be built on time and within } \\
\text { budget and the concessionaire is responsible for cost over-runs }\end{array}$ \\
\hline Full freeway specifications (no traffic lights) & $\begin{array}{l}\text { Installation of noise barriers, tolls and advertisements will not be } \\
\text { allowed along the route }\end{array}$ \\
\hline $\begin{array}{l}\text { Five interchanges offering access on or off the highway } \\
\text { at Gateway Blvd/Calgary Trail (Highway 2), 91st } \\
\text { Street, 50th Street, 17th Street and Highway 14/216 }\end{array}$ & $\begin{array}{l}\text { The province will not start paying for the facility until it opens } \\
\text { to traffic. After opening the province will make monthly } \\
\text { payments to the concessionaire over the } 30 \text {-year contract period }\end{array}$ \\
\hline $\begin{array}{l}\text { Four flyovers (bridges over/under the highway with no } \\
\text { on or off ramps) at } 34 \text { Street, 66th Avenue, 34th } \\
\text { Avenue and Parsons Road }\end{array}$ & $\begin{array}{l}\text { Including a 30-year warranty period the new facility must be } \\
\text { designed, constructed, operated and maintained according to } \\
\text { technical standards and specifications to ensure that the client } \\
\text { and user needs are met or exceed }\end{array}$ \\
\hline
\end{tabular}

The entire new infrastructure facility was assumed to have a potential impact along the corridor and across the province in terms of providing economic growth, fulfilling the user needs and achieving VFM benefits. Therefore, the successful implementation of the design standards and technical specifications is considered as fundamental to meet the following objectives (Alberta, 2004):

- Provide new effective and efficient highway infrastructure.

- Ensure safety and reliability of the travelling public.

- Ensure the new facility meets the overall life-cycle performance in an environmentally responsible manner based on specified Provincial or Federal standards. 
- Ensure the risks are allocated in an efficient way between the public and the private sectors and the party best able to manage and mitigate them is identified.

- Ensure the VFM benefits are achieved through the optimization of life-cycle capital costs.

- Provide a world class model highway by integrating the entire project components in such a way to ensure that output specification are effectively executed and the life-cycle project performance is successfully achieved.

\subsection{Performance-Based PSOS of Southeast Leg Ring Road}

The performance-based PSOS for the new infrastructure facility have been prepared in accordance with the design standards and technical specifications, particularly specified in Schedule 18 of the procurement documents. These specifications are carefully reviewed and processed to ensure that the minimum performance requirements in regards to the design, construction, operation, maintenance and rehabilitation are delivered in a cost-effective manner with the purpose of fulfilling the client needs. A detailed conceptual framework of output specifications for the Southeast ring road involving design and construction specifications, operation and maintenance specifications is established and developed as shown in Table 5. 
Table 5. A conceptual framework of performance-based PSOS for the Southeast Ring Road.

\section{Design and Construction Output Specifications}

\begin{tabular}{|c|c|c|c|}
\hline $\begin{array}{c}\text { Geometric Design } \\
\text { Requirements }\end{array}$ & Design Specifications & Construction Specifications & $\begin{array}{c}\text { Structural Specifications for } \\
\text { Bridges }\end{array}$ \\
\hline $\begin{array}{l}\text { Design speed, vertical grades, } \\
\text { cross roads, ramp terminals, } \\
\text { lane width, inside and outside } \\
\text { shoulder width, pavement } \\
\text { sideslopes, bridge headslopes, } \\
\text { ditch backslopes, vertical and } \\
\text { horizontal clerances, stopping } \\
\text { sight distances, medians etc. }\end{array}$ & $\begin{array}{l}\text { Design Vehicles, rumble strips, } \\
\text { energy attenuator system, } \\
\text { bridge barrier and parapets, } \\
\text { detailed design drawings and } \\
\text { reports, design plans and } \\
\text { profile, design cross-sections, } \\
\text { signing, lighting, roadside } \\
\text { hazards, pavement design } \\
\text { report, bridge structures design } \\
\text { report, drainage design report, } \\
\text { aesthetics, safety audits. }\end{array}$ & $\begin{array}{l}\text { As-built information (construction } \\
\text { report and surfacing information), } \\
\text { As-built pavement structural } \\
\text { Information (width and thickness } \\
\text { diagrams, soil classification, } \\
\text { pavement structure thickness), As- } \\
\text { built bridge structures ( shop } \\
\text { drawings, weld procedure, stress- } \\
\text { strain curves, precast concrete } \\
\text { girders, concrete and asphalt mix } \\
\text { design, concrete test design, } \\
\text { foundation records), As-built } \\
\text { drawings ( bridge structures, } \\
\text { horizontal and vertical alignments, } \\
\text { cross-section elements, } \\
\text { intersection layouts, interchanges, } \\
\text { utilities and conduits description). }\end{array}$ & $\begin{array}{l}\text { Bridge design codes, } \\
\text { geotechnical requirements, pier } \\
\text { foundations, retaining walls, } \\
\text { cast-in-place concrete, precast } \\
\text { concrete units, post-tensioning, } \\
\text { overhead, cantilever structures, } \\
\text { construction joints, concrete } \\
\text { curing techniques, formwork } \\
\text { erection, strength requirements. }\end{array}$ \\
\hline
\end{tabular}

\begin{tabular}{|c|c|c|c|}
\hline Drainage Specifications & Roadway Specifications & $\begin{array}{c}\text { Roadway Lighting } \\
\text { Specifications }\end{array}$ & $\begin{array}{c}\text { Signing and Pavement } \\
\text { Markings }\end{array}$ \\
\hline $\begin{array}{l}\text { Storm water management } \\
\text { facility, drainage basin, smooth } \\
\text { wall steel, pipes, catch basin, } \\
\text { manholes, reinforced concrete } \\
\text { pipes, polyvinyl chloride pipes, } \\
\text { corrugated metal pipe, pipe } \\
\text { arches, storm sewer, curbs and } \\
\text { gutter. }\end{array}$ & $\begin{array}{l}\text { Traffic control devices, signs, } \\
\text { traffic signals pedestrian control, } \\
\text { pavement markings, weather } \\
\text { information system, inspections, } \\
\text { noise walls, berms etc. }\end{array}$ & $\begin{array}{l}\text { Lighting standards, poles, } \\
\text { electrical cables, luminaires, } \\
\text { distribution enclosures, bases, } \\
\text { underground electrical conduit and }\end{array}$ & $\begin{array}{l}\text { Mainline overhead signage, } \\
\text { mainline shoulder mounted } \\
\text { signage, reflective sheeting sign } \\
\text { posts, guardrails, post traffic } \\
\text { delineators }\end{array}$ \\
\hline
\end{tabular}


Operation and Maintenance Output Specifications

\begin{tabular}{|c|c|c|c|}
\hline General Requirements & $\begin{array}{l}\text { Inspection, Emergency and } \\
\text { Routine Maintenance }\end{array}$ & $\begin{array}{c}\text { Winter Maintenance Operation } \\
\text { Requirements }\end{array}$ & $\begin{array}{c}\text { Landscape Maintenance and } \\
\text { Weed Control }\end{array}$ \\
\hline $\begin{array}{l}\text { In-service safety review, } \\
\text { imminent danger repair, lane } \\
\text { closure requirements, } \\
\text { compliance with performance } \\
\text { standards, maintenance and } \\
\text { rehabilitation standards, } \\
\text { responsibility for operations, } \\
\text { traffic volume payment } \\
\text { adjustments. }\end{array}$ & $\begin{array}{l}\text { Roadway inspections (road } \\
\text { condition, weather issues, repair } \\
\text { requirements, sign conditions), } \\
\text { Routine observations (damaged } \\
\text { signs, damaged structures, } \\
\text { burned out lights, required } \\
\text { cleaning or snow removal), } \\
\text { replacing regulatory signs, } \\
\text { traffic signals, natural disasters, } \\
\text { adequate marking, reinstalling } \\
\text { sign posts, annual inspection, } \\
\text { removing blockages in the } \\
\text { drainage system, daily road } \\
\text { reports. }\end{array}$ & $\begin{array}{l}\text { Snow clearing and ice control, } \\
\text { litter clean up, annual highway } \\
\text { clean up, traffic control and } \\
\text { weather information, regular } \\
\text { inspection and reporting }\end{array}$ & $\begin{array}{l}\text { Relocation of trees, planting, } \\
\text { fencing, weed control signage } \\
\text { and notification, moving and } \\
\text { fence trimming, maintenance } \\
\text { of seeded areas, grass cutting }\end{array}$ \\
\hline Topsoil and Seeding & Environmental Concerns & Special Events & $\begin{array}{l}\text { Management Systems and } \\
\text { Plans }\end{array}$ \\
\hline $\begin{array}{l}\text { Uniform topsoil, wheat grass, } \\
\text { slough grass, foul bluegrass, } \\
\text { June grass, establishment of } \\
\text { seeded areas }\end{array}$ & $\begin{array}{l}\text { Wet land compensation, } \\
\text { campsites, burning, historical } \\
\text { resources, pollutants, topsoils, } \\
\text { organic materials }\end{array}$ & $\begin{array}{l}\text { Full lane availability events } \\
\text { (installation of special banners or } \\
\text { special signs, adjustments of } \\
\text { traffic signals, additional traffic } \\
\text { management or traffic } \\
\text { accommodation measures), } \\
\text { Partial or full closure events } \\
\text { (installation of special signs, } \\
\text { additional traffic management, } \\
\text { traffic accommodation } \\
\text { measures). }\end{array}$ & $\begin{array}{l}\text { Quality management system, } \\
\text { environmental management } \\
\text { system, monitoring and } \\
\text { inspection program, traffic and } \\
\text { safety management plan, } \\
\text { schedule plan, construction } \\
\text { management plan, operation } \\
\text { and maintenance plan, public } \\
\text { communication plan, } \\
\text { infrastructure life-cycle } \\
\text { management plan. }\end{array}$ \\
\hline
\end{tabular}




\subsection{Key Findings and Discussion}

The reviewed documents for both infrastructure projects, show significant similarities in terms of the design and construction methodology needed to deliver the incentive as well as the operation and maintenance aspects. Even though the selected projects belonged to different provinces, the provision of all delivery services was to ensure compliance with technical standards and performance measures in order to meet the client needs. As a result the main objective for both infrastructure projects was to promote the economic growth and enhancing the quality of life. For both projects the performance target was achieved using the DBFO delivery approach between public and private sectors. The private sector was responsible for the design, construction, operation and maintenance of the new infrastructure facility over the life-cycle contract period. Through the successful implementation of technical standards and performance-based PSOS by the private sector, the overall life-cycle performance was successfully accomplished.

Notwithstanding, for both infrastructure projects there are some differences which need to be emphasized. Referring the Sea-to-Sky highway project, the main purpose was to improve safety, reliability and capacity. By developing and incorporating design and construction innovations, the functional requirements of the project were attained in terms of reducing hazards, shortening travel times and an increase in highway capacity. More than half of the design and construction of the new facility was performed by the private sector using the PPP approach while the remaining part was delivered by the province using a series of DB contracts under the traditional approach. The overall baseline improvements of the highway, along the concession period, involving additional passing lanes, median barriers, straightening lanes and wide shoulders were effectively delivered using a total capital cost of $\$ 600$ million and including a long term concession period of 25 years.

On the other side, the Anthony Henday Drive Southeast Leg Ring Road was the first highway in the Province of Alberta which is delivered using a made-in-Alberta PPP approach. The design, construction, operation, maintenance and rehabilitation of the new ring road was performed in accordance to the functional plan and technical specifications defined in the contract agreement. Compared to the Sea-to-Sky highway improvement project, the Southeast leg ring road was built on fully freeway specifications meaning that all interchanges, flyovers and overpasses were in place prior to opening. One of the key features of the Southeast leg ring road compared to the other PPP projects is that the installation of noise barriers, toll roads and advertisements was not allowed along the entire length of the route. Including a 30year concession period the new infrastructure was successfully delivered under a total capital cost of $\$ 493$ million. 
Whereas, the performance-based PSOS relies in a chronological barrier, commencing from the statement of client requirements or client needs to achieve the performance target, the two case studies affiliate prescriptive behavior leaning more towards the input-based technical specifications. Most of the technical aspects are compiled in such a way to allow much synergy and flexibility for the private sector to ensure that the designed end product is attained through the development of innovative and cost-effective solutions. For instance, in the Schedule 18 (pg. 35) document of the Southeast leg ring road was accentuated:

"According to the durability provisions, the bridge structures shall be designed for a service life of 75 years... The functional plan shows construction of the centre lanes on the mainline in Stage 1.

Alternatively, the contractor may construct the outside lanes instead of the centre lanes in Stage 1, and allow future mainline widening to occur to the inside..."

The aforementioned paragraph clearly notes what is required rather than how it is to be performed. The design life of bridge structures is defined to meet the minimum life-cycle requirements but is not further detailed how the output should be evaluated. Therefore, the responsibility to meet or exceed the life-cycle performance belongs to the private sector. Also the paragraph underline the flexibility of the private sector to accommodate innovative features in accordance with the specified criteria and designed outputs established by the public sector.

Although the examples of PSOS are distinguishable in both cases, the performance measures signify that the performance-based PSOS are more applicable to the Sea-to-Sky highway improvement project. This is observed in various categories of PSOS such as geotechnical specifications, traffic operational requirements, construction timeline, and performance payments. Even though, the performance measures were properly defined and adequate performance measurement methods were adopted, the use of a systematic engineering methodology is recommended.

However, it should be noted that each infrastructure project has its own specifications and these specifications are dependent form the surrounding environmental conditions, governmental laws and regulations and life-cycle statutory requirements. 


\section{Conclusions and Recommendations}

The development of performance-based PSOS for PPP infrastructure projects has been considered a challenging task for many governmental agencies and public authorities. Due to the complexity in nature and substantial impact that PPP infrastructure projects contain, it is difficult to specify all the output requirements right at the outset. Therefore, the development of PSOS require more time, efforts and technical expertise compared to the prescriptive specifications. Whereas, the input-based specifications are developed to serve only as a supplementary prescription of the design to the detailed design drawings, the performance-based PSOS needs to provide an overarching description by covering not only the state of the build facility, but also the performance specifications of the operation, maintenance and rehabilitation of the facility to be built by the preferred proponent. As a result, the following conclusions were drawn:

- The current practice of PSOS and the performance measures to improve the current practice are emphasized.

- The most critical criteria to develop a high quality PSOS are also evaluated including:

a) A complete hierarchy of the performance breakdown structure.

b) Clearly defined performance measures.

c) Completely implementable performance measurement methods.

d) A firm and economically justified performance target.

- Based on the proposed criteria and following the principles of system engineering approach, a new generic framework for developing high quality PSOS for PPP infrastructure projects is proposed. The proposed framework would be helpful for both the public and the private sectors ensuring that the performance delivery of the project is achieved in a qualitative and quantitative manner.

- In compliance with the performance measures the PSOS must be effectively developed, based on the hierarchy of the system performance, to successfully meet the client needs.

- Whereas, the input-based technical specifications are prepared using a bottom-up approach, in this study the performance-based PSOS are developed using the top-down approach. The top-down approach is used to ensure that the designed end product is achieved in accordance to the required performance measures in a cost-effective way.

- The results obtained from the case studies, indicate that performance-based PSOS were successfully developed and implemented through the accomplishment of performance measures and performance measurement methods. However, the use of a systematic engineering methodology would bring more comprehensive results in terms of developing better PSOS and enhancing the life-cycle performance. 
- The generic framework proposed among this study, can be used alongside other PSOS documents published by the public sector and can help in improving the current practice in terms of developing more robust PSOS for ongoing PPP projects.

- A future study to develop a standardized template of PSOS for PPP infrastructure projects is recommended. 


\section{References}

Akbiyikli, R., Eaton, D., \& Dikmen, S. (2012). Achieving sustainable construction within private finance initiative (PFI) road projects in the UK. Technological and Economic Development of Economy, $18(2), 207-229$.

Cheung, E., Chan, A., \& Kajewski, S. (2009). Enhancing value for money in public private partnership projects. Journal of Financial Management of Property and Construction, 14(1), 7-20.

Siemiatycki, M. (2013). The Global Production of Transportation Public-Private Partnerships. International Journal of Urban and Regional Research, 37(4), 1254 - 1272.

(2000). Retrieved September 25, 2016, from Department of Environment, Community and Local Government: http://www.environ.ie/sites/default/files/migratedfiles/en/Publications/DevelopmentandHousing/PPP/FileDownLoad,1748,en.pdf.

(2004). Retrieved October 10, 2016, from The Scottish Government: http://www.gov.scot/Resource/Doc/25954/0023741.pdf.

(2014). Retrieved February 5, 2016, from PPP Canada: http://www.p3canada.ca/ /media/english/resourceslibrary/files/p3\%20a\%20guide\%20for\%20federal\%20departments\%20\%20agencies.pdf.

Akintoye, A., \& Beck, M. (2009). Policy, finance \& management for public-private partnership. WileyBlackwell.

Alberta. (2004, October 22). Retrieved January 22, 2016, from www.transportation.alberta.ca: http://www.transportation.alberta.ca/Content/docType353/Production/Schedule-18-Oct-22-04_Appendices-1-12_.pdf

Blanchard, B. (2008). System engineering management (4th edition ed.). Wiley.

Foster. (2012, August). Best Practice in Design of Public-Private Partnerships (PPPs) for Social Infrastructure, particularly in Health Care and Education. Retrieved October 10, 2016, from http://www.apec.org.au/docs/Best\%20practice\%20in\%20design\%20for\%20social\%20infrastructu re\%20PPPs.pdf.

Fraser Institute. (2013). Retrieved October 5, 2016, from Using Public-Private Partnerships to Improve Transportation Infrastructure in Canada: https://www.fraserinstitute.org/studies/using-publicprivate-partnerships-to-improve-transportation-infrastructure-canada.\#sthash.mvR7ptvH.dpuf

Himmel, M. (2015). Infrastructure Ontario. Retrieved January 5, 2016, from EVOLUTIONARY TO REVOLUTIONARY: UNDERSTANDING INNOVATION! IN INFRASTRUCTURE PROJECTS THROUGH PUBLIC-PRIVATE PARTNERSHIPS:

http://www.infrastructureontario.ca/WorkArea/DownloadAsset.aspx?id=2147492765.

HKIS. (2009). Practical Guide to Public Private Partnership (PPP). Hong Kong: Hong Kong Institute of Surveyors. Retrieved October 10, 2016, from http://www.psdas.gov.hk/content/doc/2005-111/PDP\%20-\%202005-1-11.pdf 
Infrastructure Ontario. (2007). Retrieved November 15, 2016, from Assessing Value for Money, A Guide to Infrastructure Ontario`s Methodology: http://www.infrastructureontario.ca/WorkArea/DownloadAsset.aspx?id=2147488713.

Infrastructure Ontario. (2012). Value for Money Assessment. Infrastructure Ontario. Retrieved October 15, 2016, from www.infrastructureontario.ca

Infrastructure Ontario. (2013). Retrieved September 25, 2016, from 10-Year Economic Impact Assessment of Public-Private Partnerships in Canada: http://www.infrastructureontario.ca/WorkArea/DownloadAsset.aspx?id=2147492265.

Infrastructure Ontario. (2015). Retrieved November 15, 2016, from Assessment of Innovation through AFP Project Delivery: www.infrastructureontario.ca

Javed, A. A., Lam, P. T., \& Chan, A. P. (2013). A model framework of output specifications for hospital PPP/PFI projects. Facilities, 31(13/14), 610-633.

Javed, A., Lam, P., \& Zou, P. (2013). Output-based specifications for PPP projects: lessons for facilities management from Australia. Journal of Facilities Management, 11(1), 5-30.

Javed, A., Lam, P., \& Chan, A. (2014). Change negotiation in public-private partnership projects through output specifications: an experimental approach based on game theory. Construction Management and Economics, 32(4), 323-348.

Kim, M., Mohammad, L., Challa, H., \& Elseifi, M. (2015). A simplified performance-based specification for asphalt pavements. Road Materials and Pavement Design, 16(S2), 168-196.

lacobacci, M. (2010). Dispelling the Myths: A Pan-Canadian Assessment of Public-Private Partnerships for Infrastructure Investments. The Conference Board of Canada. Retrieved October 22, 2016, from http://www.fengatecapital.com/DispellingTheMythsRpt_WEB1.pdf

Ministry of Infrastructure Renewal. (2004). Retrieved November 5, 2016, from Building a Better Tomorrow: An Infrastructure Planning, Financing and Procurement Framework for Ontario`s Public Sector: http://www.pir.gov.on.ca/

OCG. (2008). Retrieved November 15, 2016, from Office of Government Commerce: http://webarchive.nationalarchives.gov.uk/20110601212617/http:/www.ogc.gov.uk/documents/In troduction_to_Public_Procurement.pdf

Partnerships BC. (2003). Retrieved October 15, 2016, from An Introduction to Public Private Partnerships: http://www.partnershipsbc.ca/pdf/An\%20Introduction\%20to\%20P3\%20June03.pdf.

Partnerships BC. (2006, November 14). Retrieved January 22, 2016, from http://www.partnershipsbc.ca/pdf/sts-all-schedules-14-nov-06.pdf

Regan, M., James Smith, \& P. E. D, L. (2015). Better infrastructure procurement for public private partnerships: An Australian perspective. 5th International/11th Construction Speciality Conference (p. 10). Vancouver: CSCE. Retrieved October 10, 2016, from www.researchgate.net/profile/Peter_Love2/publication/274195678_Better_Infrastructure_Procure ment_for_PPPs_An_Australian_Perspective/links/5518d9ba0cf2f7d80a3e3236.pdf 
Robinson, H., \& Scott, J. (2009). Service delivery and performance monitoring in PFI/PPP projects. Construction Management and Economics, 27(2), 181-197.

Russell, A., Tawiah, P., \& Zoysa, S. (2006). Project innovation - a function of procurement mode? Canadian Journal of Civil Engineering, 33(12), 19.

Siemiatycki, M. (2015). Public-Private Partnerships in Canada: Reflections on twenty years of practice. Canadian Public Administration, 58(3), 343-362.

Siemiatycki, M., \& Farooqi, N. (2012). Value for money and risk in public-private partnerships: evaluating the evidence. 78(3), 286-299.

Vining, A., \& Anthony E, B. (2008). Public-private partnerships in Canada: Theory and evidence. Wiley Online Library, 51(1), 9-44.

Yuan, J., Miroslaw J, S., Qiming, L., \& Alex Yajun, Z. (2009). Selection of performance objectives and key performance indicators in public-private partnership projects to achieve value for money. Construction Management and Economics, 27(3), 253-270. 